\title{
Psicología y ecología, o del instinto en el orden de la naturaleza
}

\author{
Por Honorio Delgado
}

El hombre típico de la civilización moderna, con gran simpleza, se ufana de ser superior al medioeval por creerse práctico y adicto a las cosas de este mundo. Pero en verdad sólo conoce el apetito de goces materiales y el propósito utilitario frente a lo terrenal, sin un efectivo amor a la naturaleza. Así la presunción de nuestro civilizado se funda en un doble error, ya que, desarraigado del cosmos, carece de afición a lo genuino de cada ser y desconoce la positiva simpatía del hombre medibevaloparą das drias dedas creación. En el dominio del pensāmientercientíficoclanfalț ode penetración de lo genuino favorece el afán de reducir la entidad de los fenómenos anímicos a los principios de la biología y las manifestaciones de la vida a la causalidad propia de la materia inanimada, como si los hechos físicos y químicos fuesen principales o la realidad última.

Desarrollando un tema del cual me he ocupado antes, intento mostrar aquí cómo el mundo en que vivimos se ordena de manera orgánica y rfinalista, cómo se impone el modelo psicológico en la comprensión de la naturaleza, como si el conjunto de la materia obedeciese a la dirección' del espíritu - mens agitat molem, et magno se corpore miscet, se- 
gún el verso de Virgilio. Con este fin me bastará relacionar una serie de hechos científicamente comprobados, cuya sola consideración maravilla y es capaz de hacer amar a la nanaturaleza, sentimientos $\sin$ los cuales no se adquiere una sensata concepción del mundo.

\section{Disposición biogenética de la materia inorgánica}

Contrariamente a la concepción de la vida como un mero accidente de la superficie terrestre, el estudio de las substancias químicas abundantes en ésta evidencia que sus propieđades son específicamente adecuadas a la economía de animales y vegetales. Hace más de un siglo Wheweics sostenía que muchas de las propiedades de la materia "parecen escogidas precisamente para la vida", y L. J. Henderson, en su libro The fitness of the environment (Nueva York, I9I3), con una masa imponente de datos y con un rigor analítico inobjetable, sostiene la tesis de que nuestro mundo está formado de tal modo como si obedeciese al designio de

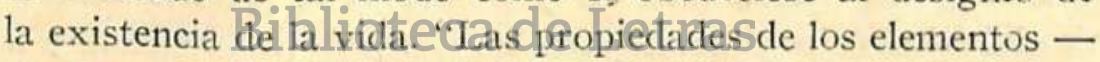

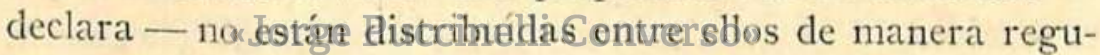
lar y correspondiente al sistema periódico, ni de un modo que pueda explicarse como casual; por el contrario, si consideramos los límites exteriores, están distribuídas de la manera más desigual, de suerte que las cualidades más prominentes se presentan concentradas principalmente en algunos elementos especiales, y en primera línea en el oxígeno, el hidrógeno y el carbono. Esta distribución condiciona algunas consecuencias extremadamente importantes para el desenvolvimiento cósmico y orgánico, a saber, una máxima consistencia e invariabilidad de los estados físico-químicos de la superficie de un planeta así como una máxima compli- 
cación de la síntesis de los mismos. Tiene también por consecuencia que en tal superficie puedan existir y conservarse sistemas de alta estabilidad, complicación y riqueza de energía... El proceso total del desenvolvimiento es unitario tanto del cósmico cuanto del orgánico".

A manera de ejemplo señalaré las peculiaridades del principal compuesto de oxígeno e hidrógeno, el agua, y las del carbono. El agua, que al observador vulgar parece el compuesto más anodino y a un poeta, "la inocencia de la naturaleza”, entraña una serie extraordinaria de propiedades óptimas para la regulación orgánica y el buen acondicionamiento vital del medio ambiente, propiedades que no se presentan reunidas en ningún ot:o fiquido, siendo el agua el más abundante en la superficie de la tierra $y$, cuantitativamente, el principal componente de todos los organismos desarrollados. Sus cualidades biggeneticas mas importantes son: un elevado calor específico, un gran calor latente de licuefacción y evaporación, buena conducción del calor (excepcional fuera de los metales), el punto de máxima densidad a $4^{\circ}$ sobre

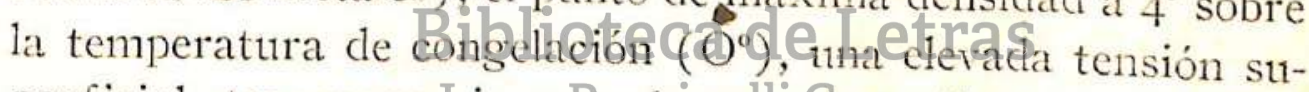

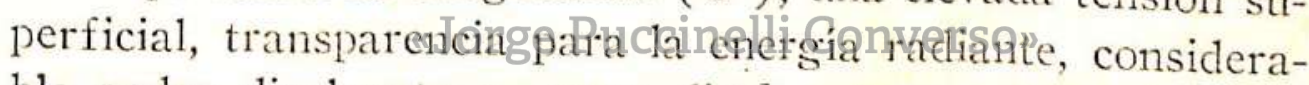
ble poder disolvente $y$, como disolvente, inercia química $y$ constancia dieléctrica grandes, multiplicidad de asociación de sus moléculas (como monohidrol, dihidrol, trihidrol, "agua pesada"). El carbono, elemento químico inherente a todas las materias orgánicas, tiene características químicas singularísimas, que dan a sus compuestos aptitudes únicas para la actividad fisiológica. Se destacan las siguientes: la capacidad de unirse a cualquier otro elemento, que permite una gran variedad de combinaciones; la tetravalencia de su átomo, la cual hace posible un enorme número de derivados de cada comptiesto de que forma parte, con grados cle comple- 
jidad y modos de estructura innumerables; su posición en el sistema periódico, entre los elementos positivos y los negativos, que le permite combinarse con unos y otros y alternar la oxidación y la reducción, y, gracias a eso, actuar como vehículo de energía; la lentitud de reacción o la inercia de sus compuestos, particularmente significativa para los fenómenos vitales.

Parece que hasta la proporción de las sales disueltas en el océano primitivo, de donde salieron los primeros animales, haya sido particularmente adecuada a la economía de la vida. En efecto, no se puede explicar de manera más satisfactoria las verificaciones de la paleoquímica de los flúidos animales y del marino, iniciada en 1889 por Bunge y sobre la cual ha concebicto Quinton nua ingeniosa teoría. El hecho positivo es que gracias a los métodos recientes de investigación se puede asegurar, con un margen limitado de error, que la concentración salina del plasma sanguíneo y de la linfa cle los vertebrados actuales corresponde a la proporción de sodio, potásid, catcied thagnesion disueltos en el mar de

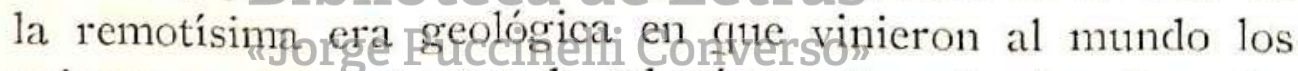
primeros representantes de tal género de animales. La misma "fidelidad" al mundo primigenio se observa también en los invertebrados. Incluso en las especies cuyo medio actual es el océano, la concentración salina de sus humores corresponde (tanto por la canticlad relativa al disolvente cuanto por las proporciones de las diversas sales) a la del medio exterior arcaico y no a la del actual, mucho más cargado de sales. Así, a lo largo de decenas de millones de años en el medio interior de los animales perseveran las proporciones originales, a despecho del incesante y desigual aumento de las diversas sales disueltas en el mar. Esto evidencia, ade- 
más de lo dicho, que el organismo vivo no es influído pasivamente por el ambiente cuando no le conviene, lo cual resalta todavía más claramente en el hecho de que en el núcleo de la célula normal el agua no contiene ninguna materia inorgánica, a pesar de abundar ésta en el resto de la célula circunstancia peculiarísima debida muy probablemente a la conveniencia de proteger la invariabilidad de la substancia hereditaria de que es asiento el núcleo.

Por último, el estado coloidal, o sea de suspensión de finísimas partículas de una substancia en medio de otra, estado en el cual se halla casi toda la materia en el organismo, es otra condición sin la cual la vída no sería posible, pues gracias a él los cuerpos se hallan a la vez en un estado dinámico y los cambios químicos se operan sin violentos desarrollos de energía. Ahorablen, en este estado se encuentra asimismo parte de la materia inorgánica de la superficie terrestre, lo cual igualmente es ventajoso para la vida. Los coloides del suelo protegen a las plantas contra los metales venenosos y neutralizmi losi matos efectos del cambio de la alcalinidad o acidez de las tiertas sebre da respiración de sus raices. En realidad todas estas investigaciones son los primeros pasos en el camino de la inteligencia de la adaptación del medio a la vida, hecho complementario de la adaptación de la vida al medio, la única que considera la biología materialista. $E_{11}$ tal perspectiva es pertinente la siguiente afirmación de Teilfiard de Chardjn: "Considerada en sus comienzos y en sus orientaciones principales, la vida no principiará a ser comprendida científicamente sino cuando se haya descifrado la historia físico-química del astro del cual ella es la envoltura consciente". 
La luz solar y la economía de la bioesfera

Los hechos que he considerado en primer lugar muestran una correspondencia innegable entre las condiciones físico-químicas de la superficie de nuestro planeta y la vida que medra en ella, correspondencia reveladora de un orden ascendente en la constitución de la naturaleza. Los fenómenos que señalo en seguida, familiares a todo cultor de la biología, permiten entrever, en un panorama más amplio del mundo, la esencial y coherente actividad de la naturaleza según la concebía Aristóteles-, como la sinergia de una grandiosa fisiología cuyo manantial de fuerza es el Sol y cuyo cuerpo vivo está integrado por el conjunto de animales y plantas, en centricho inmediato y productivo con el reino mineral.

Las plantas verdes, gracias a la clorofila, absorben la luz solar y la transforman en energía química. Este fenómeno, llamado fotosintesis, consiste, según el criterio generalmente aceptado, en que la clorofila unida al protoplas-

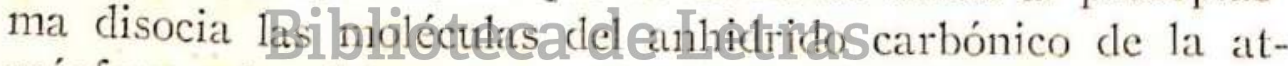

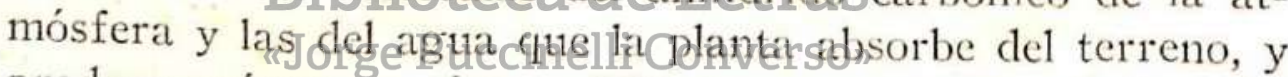
produce azúcar y oxígeno. Ulteriores procesos químicos del vegetal integran las moléculas del azúcar formando almidón. Según investigaciones recientes, el almidón no procedería, en la planta, đe un azúcar (sacárosa o maltosa) sino de un ester de glucosa, y a la acción de la luz se debería el desprendimiento de oxígeno, mas no la absorción del anhidrido carbónico, pues ésta se manifiesta aun en la obscuriclad.

La mayoría de las personas cree que las bacterias y en general los microbios sólo son seres peligrosos, causantes de las enfermedades. En realidad, los gérmenes patógenos for- 
man la minoría de la inmensa población de los vegetales y animales microscópicos. La mayor parte son o inocuos o indispensables para la existencia de la flora y la fatma macroscópicas. Según observa Pierantoni, iniciador del estudio de la simbiosis normal hereditaria de los animales con las bacterias, "el microrganismo patógeno no se presenta sino en algunos individuos de la especie (enfermos y portaclores resistentes a la infección), mientras que el microrganismo fisiológico existe en todos los individuos de cada especie y constituye una necesidad ineludible para la vida del organismo; se transmite hereditariamente, al mismo título que otras propiedades plasmáticas y nucleares de todos los otros órganos". Las bacterias constituyen un grupo copioso e importante entre los vegetales desprovistos de clorofila. Infinidad de especies de este grupo desempeñan una función de sintesis de las substancias nitrogenadas, las cuales entran como componente prineipal del protoplasma de todas las células animales y regetales. Hay una clase de bacterias que se apoderan directamente del nitrógeno de la atmósfera y forman nitratos; algunas especies de estas bacterias fijacloras del nitrógenl lipeffibres en el stiele, al que enri-

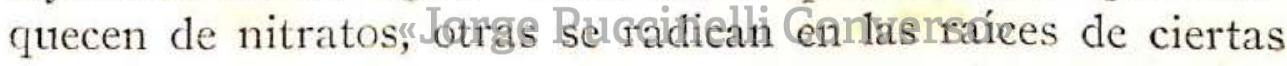
plantas, a las cuales suministran el producto de su industria. Existen otras bacterias que descomponen el protoplasma de los vegetales y animales muertos, produciendo amoníaco, el cual, a su vez, es transformado en nitritos por otro género de bacterias y, por último, un cuarto grupo bacteriano tiene la especialidad de oxidar los nitritos, convirtiéndolos así en nitratos asimilables por los vegetales verdes.

Los animales no toman del munda inorgánico sino agua, oxígeno y algunas sales; para lo demás dependen de las plantas, las cuales, por otra parte, han generado y renuevan 
el oxígeno de la atmósfera. Ellas les suministran los alimentos plásticos y los energéticos : a los herbívoros de manera directa y a los carnivoros por medio de los cuerpos de los herbivoros. Mientras que en la economía de la planta predomina el anabolismo, o sea la conversion de la energia y de la materia exterior en substancia orgánica (energía potencial), en el animal, organismo móvil y activo, sobrepuja el catabolismo, esto es, la transformación de las materias asimiladas en trabajo físico (energía quinética). A este propósito Bergson piensa que "el mismo impulso que ha llevado al animal a darse nervios y centros nerviosos ha debido conducir a la planta a la función clorofiliana".

En resumen, en el inmenso proceso metabólico de la naturaleza, en que se complementan y correlacionan las funciones de las bacterias, de las plantas verdes y de los animales, hay dos aspectos: el ciclo del carbono y el ciclo del nitrógeno. El ciclo del carbono se inicia en la planta con la formación de los hidratos de carbono - que son el combustible para el funcionamiento de todos los organismos - y el oxígeno libre. El animal se nutre de los hiclratos de carbono sintetizados por la planta $y$ uno y otra restituyen con su res-

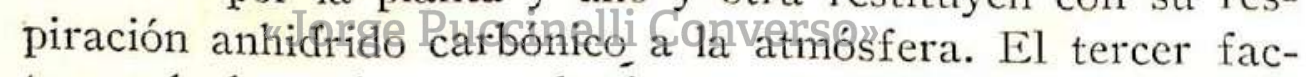
tor es la bacteria, cuyo destino es descomponer los cuerpos muertos de animales y vegetales : la fermentación devuelve al medio el agua y el anhidrido carbónico precursores de los hidratos de carbono. Así retornan las substancias a su condición original, en el proceso de la circulación sin fin. El esquema del ciclo del nitrógeno es más complejo : comienza con la intervención de las bacterias fijadoras, sigue con la síntesis de las proteinas en los vegetales, de los cuales se proveen los animales, y la putrefacción de los cuerpos de unos $\mathrm{y}$ otros, por obra de las bacterias, engendra nitritos, que 
también por industria bacteriana, se convierten en nitratos asimilables por el vegetal.

Este aspecto de la historia natural de la nutrición, ajuste de la vida y la muerte, nos muestra, pues, la totalidad solidaria de fauna y flora - la bioesfera - en la relación más estrecha y dinámica con la unidad telúrica y ésta en dependencia del conjunto del sistema solar. Posteriormente veremos cómo, en este gran ámbito đel universo, repercuten sobre la vicla el ritmo de las estaciones, el del día y la noche, el de las mareas, la gradación de climas y demás factores dependientes de la situación de cada lugar y de las transformaciones inherentes a la evolución del globo, tal y como si el conjunto fuese un gigantesco animal, según lo imaginó Platón.

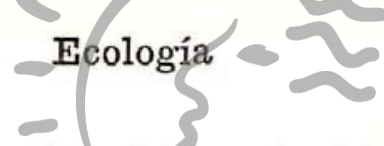

La palabra "ecología” fué introducida en el léxico científico por HAECKEL en 1866. En su obra Genereller Morphologie la define como "doctrina de la economía de los organismos". El conceptQ hiadertucionadodesteentonces y hoy

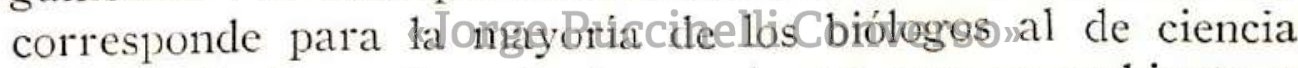
de las relaciones de animales y plantas con su ambiente y entre ellos, de la situación del ser vivo en la bioesfera. Generalmente se considera la ecología como un mero aspecto descriptivo de la zoología, y de la botánica. Pero tiende a imponerse un criterio más amplio y comprensivo, de modo que su dominio abarca los datos de todas las ciencias especiales de la naturaleza. Así, la ecología sería la disciplina central del conocimiento de la naturaleza, cuyo fin es la comprensión del ser en su campo, de las partes en función del todo, verdadera historia natural de la configuración y dinámica del complejo microcosmos-macrocosmos. Como com- 
plemento de las ciencias naturales especiales - indispensables para el saber preciso-, ciencias que tienen por meta ideal la explicación físico-matemática de los fenómenos aislados unos de otros por abstracción, la ecología busca el sentido de las manifestaciones concretas de la naturaleza según la situación local e histórica en cada caso, la razón de ser de su génesis y de sus vinculaciones reales. Mientras que las disciplinas especiales no meramente descriptivas, sistemáticas, persiguen y analizan la causalidad material por medio de artificios experimentales o discursivos, la ecología trata de aprehender, en la práctica y sobre el terreno, la estructura intima de las manifestaciones nativas, gracias a la sintesis de la observación realista de lo singular, la intuición de lo típico y la stma de los datos de las ciencias especiales. En el caso de estas tultimas la unidad a que llega el espiritu es el elemento constitutivo, lograda por abstracción; en el caso de la ecología es la integración orgánica supraindividual, sorprendida en sus correlaciones y en su plenitud efectiva, pues, según senteneia Claude Bernard, "el misterio de la vida po reside en la naturaleza de las fuerzas que pone en juego sino fn la dirección que les dá".

Friederichs, adalid de la ecología nueva, distingtue la investigación de las relaciones del organismo con su habitáculo, de la investigación biológica del espacio. Lo primero es tema de la ecología en sentido estricto. Esta estudia lo que clásicamente se llama el habitat y la norma ecológica de cada especie animal o vegetal, así como asociaciones y correlaciones típicas en la flora y la fauna. La investigación biológica del espacio corresponde a la ecología en sentido amplio. Estudia las relaciones recíprocas de los fenómenos naturales en general, como contenido del espacio y realización en el tiempo, por tanto, sus ritmos y gradaciones. Lo 
que hoy se llama cosmobiología es parte de su tema, la de mayor ámbito en el universo. Friederichs precisa la tarea de la ecologia en estos términos : "Cuestión principal de la ecología biocéntrica es la comprensión del organismo y del mundo donde reside. Ahí se incluye las periodicidades biológicas, climáticas y cósmicas y sus relaciones, y el aumento o mengua en el movimiento de la población humana y de los animales. La investigación comparada del espacio tiene una fase inicial descriptiva: el reconocimiento de lo que se encuentra yuxtapuesto en los mismos ámbitos vitales, como base de la indagación de por qué ocurre necesariamente esta yuxtaposición. Esta investigación conduce de modo regular - a través del conjunto de la naturaleza, terreno, clima, commniclad vital - al conocimiento preciso de la región correspondiente, al de amplias zonas geográficas, abarcando los clatos del pasado y el presente en una exploración en profundidad que desborda considerablemente los fines de la geografía. Pero las mayores tareas de la ecología se presentan en el dominio práctico : todo lo que se refiere a la conservación o perturbacióndel equilibrio de la naturaleza : desmonte de terrenos y bosques, desecacion y riego, trabajos de aluvión, sistemas economicos favorables y adversos a la naturaleza en materia de silvicultura y agricultura, con sus consecuencias de plagas de insectos y enfermedades de las plantas. También el conocimiento de las epidemias del hombre y de los animales tiene su aspecto ecológico, y, por sus consecuencias, corresponde a la ecología la protección de la naturaleza".

En lo que sigue de este trabajo expondré gran variedad de correspondencias ecológicas extremadamente significativas para la filosofía de la naturaleza. Ahora mencionaré sólo un ejemplo impresionante de la importancia práctica de la ecología, que además ilustra el finalismo de las 
correlaciones entre el clima y la vegetación así como el peligro de la explotación desconsiderada de la naturaleza por el hombre. Como es sabido, las plantas requieren humedari atmosférica para prosperar, y donde abundan la atraen. De ahí que en parajes áridos en los cuales se logra cultivar árboles en número considerable, acaban por presentarse las lluvias; por el contrario, en regiones donde se desmonta sin medida, sobreviene la sequía y la muerte. Esto último se ha verificado en el norte de Africa, en Sicilia, Dalmacia, Turquía, Persia etc. R. Albert considera que la đecadencia de las culturas primitivas de Sudamérica no se debe tanto a la conquista española cuanto al desmonte practicado previalmente por los aborígenes. $Y$ C. W. Cooke ha probado que el fin del Imperio Maya en Centroamérica tiene su origen en la sequía producida por la destrucción de los bosques, substituídos por sembríos de maíz y otros frutos. Con la falta de lluvias que sigue a esto, disminuye el agua de los lagos y éstos acaban por convertirse en ciénagas donde pululan mosquitos transmisores de enfermedades mortíferas. La malaria y la fiebrécamarilla en poces años - probablemente del 580 al 530 despues de J C.- aniquilan la densa población de catorce milfones de habitantes y una gran civilización. La explicación de Cooke no es conjetural sino resultado de prolijas investigaciones en las capas del terreno, archivo de la inmensa catástrofe.

\section{Solidaridad entre animales y vegetales}

Como es sabido, existe una serie de formas de asociación biológica đe los organismos, entre las cuales las más típicas y frecuentes son el comensalismo, la simbiosis y el parasitismo, descritas en todos los manuales. Se presentan sea entre individuos de dos especies vegetales o animales, sea 
entre una planta y un animal. El último caso es universal, pues no existe animal que no viva en simbiosis o comensalismo con bacterias o no sea parasitado por ellas; según hemos visto, la regla es la simbiosis fisiológica hereditaria: bacterias para digerir substancias de otro modo inaprovechables para el organismo del animal, bacterias en la sangre o la linfa del animal, que obran como si se tratase de glándulas de secreción interna, indispensables para el metabolismo etc. Por otra parte, la compenetración del reino animal con el vegetal es infinitamente compleja. Así, cualquier trozo de tierra con vegetación es el escenario de regulaciones y luchas incontables; en todas partes los pequeños animales de presa y los minúsculos parásitos ejercen una acción de contrapeso frente a los insectos que viven de los vegetales, de suerte que se mantiene una norma ecológica, una harmonía en la varia población, sin la cual no sobrevivirian las plantas, los insectos fitófágos, sus parásitos y los animales de presa. A estos factores en equilibrio se agrega la influencia del clima. En efecto, al comienzo de la primavera los vegetales crecen rápidâmente, mientras tanto los insectos, que necesitan más calor "Dara medrar, demoran en desenvolverse y son poco activos. "Si las cosas cesasen de ser asi, pronto desaparecerían los vegetales, devorados por los insectos, y con eso, prácticamente, terminaría la vida sobre la Tierra.

Pero la fina coordinación de la bioesfera, la concordancia de fines en la vida de los seres, explicables sólo como realización de una idea, de un plan, se hacen realmente patentes al considerar los casos particulares, de los cuales examinaremos algunos perfectamente comprobados. Uno, ilustrativo de la simplificación del gran ciclo del metabolismo del carbono en la naturaleza, lo ofrece la convoluta roscoffensis, gusanillo plano que vive a la orilla del mar, visible 
en la superficie cuando la marea es baja y oculto en la arena cuando sube la marea por encima del nivel de su habitáculo. Su color verde obscuro lo debe al considerable núniero de algas simbióticas. Gracias a esta conjunción del animal con el vegetal, cuando la convoluta llega al estado adulto no necesita tomar alimentos, pues así como durante su desarrollo se nutre de los cuerpos de las algas, en la madurez recibe directamente los hidratos de carbono y las grasas que producen las que lleva vivas en su cuerpo. Para que se opere semejante producción de substancias nutritivas las células verdes del alga requieren iluminación óptima; la foton sintesis se logra gracias a la exposición que el gusanillo hace de su organismo en la superficie de la arena durante toda la bajamar. Por otra parte, en virtud de la situación que el animal mantiene cuidadosamente a mitad de la altura de la orilla, conserva el grado de humedad indispensable a su vida con la inmersión mientras se prolonga la pleamar. Cuando se aproxima una tempestad la convoluta se hunde rápida y profundamente en la arena, con lo cual evita ser barrida por las olas

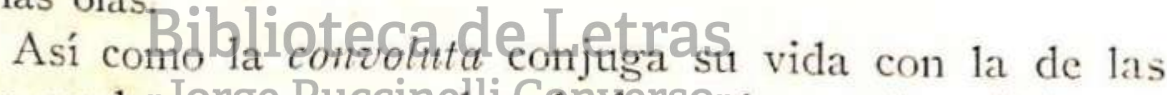

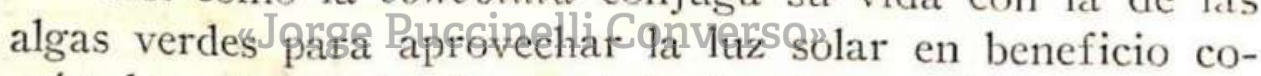
mún, hay otros animales en el fondo obscuro del mar que se sirven de bacterias fotógenas para iluminar su ambiente cuando les conviene. Pierantoni ha descubierto esta simbiosis en diversos moluscos cefalópodos y posteriormente otros investigadores la han verificado en algunos peces. El hecho es que esos animales tienen órganos, comparables con linternas, cuya fuente luminosa está constituída por cultivos de bacterias fosforescentes*. Estas linternas vivas se forman

\footnotetext{
* Tolavía se ignora el mecanismo productor de esta luz. Entre los insectos hay varias especies portadoras de linterna propia. Existen esca-
} 
por invaginación de la piel, cuyas paredes delgadas y en parte transparentes, abundantemente irrigadas por la sangre, protegen y nutren a las bacterias que ahí se multiplican. E1 receptáculo de luz se completa con órganos auxiliares, como

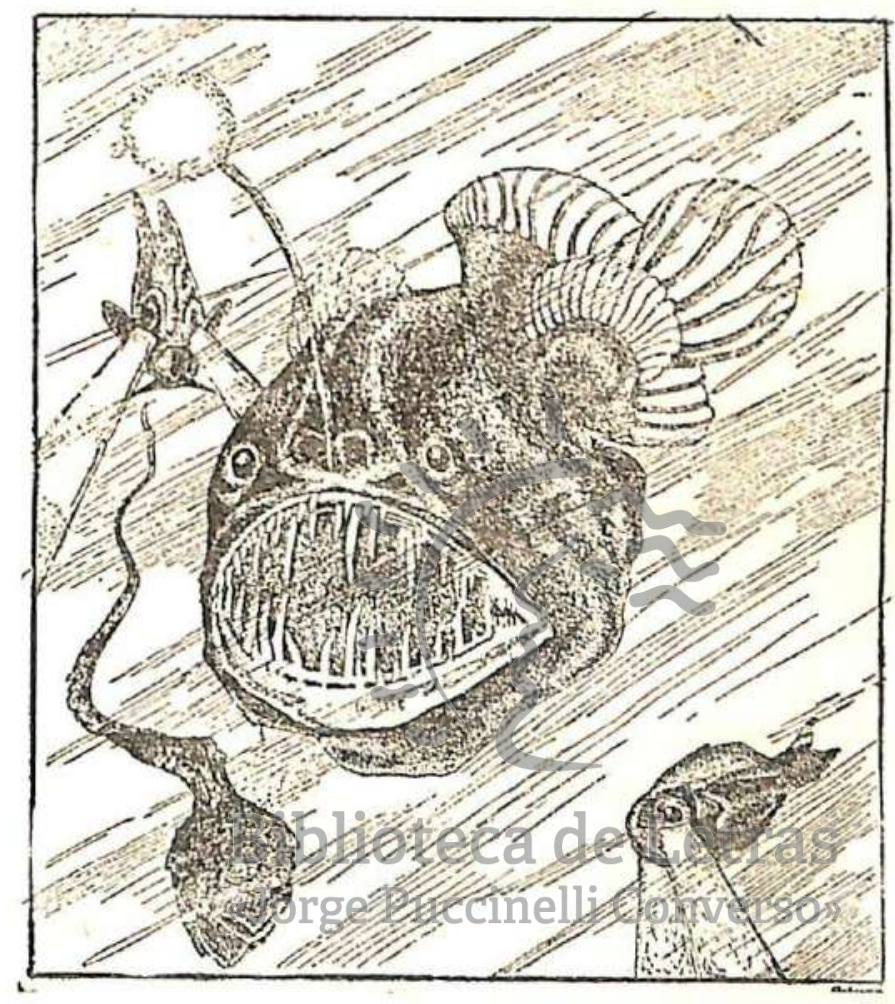

Fig. 1. Peces con linternas bacterianas.

reflectores, lentes condensadoras y antenas movibles, que permiten utilizar a la perfección el luminoso contenido (Fig. I). Algunos animales así provistos se ocultan de sus perse-

rabajos cuya iluminación, la de uno solo, permite al hombre leer el texto de un tipo corriente en plena noche. "En proporeión a su talla, el piróforo produce más luz que nuestros dínamos más poderosos". Hyatt Verrill considera "el más grande misterio de la naturaleza" la génesis de la luz fría en el enerpo de los seres vivos. Todas las investigaciones de mnehos sabios han fracasado, y tratándose de ciertos insectos luminosos, el problema más difícil es cómo puede el animal encender y apagar su luz "a voluntad”. 
guidores lanzando las bacterias al agua, de suerte que pueden huir tras el velo luminoso que dẹjan.

Tipo muty diferente de conexión vital entre animales y plantas es el de las agallas formadas' por muchos árboles, excrecencias inútiles y a veces hasta nocivas para éstos, que ofrecen alojamiento, protección y pábulo específicamente adecuados a los animales que las parasitan. ErICH BeCher ha analizado esta suerte de finalidad en servicio ajeno, y considera el "altruismo" del vegetal, que provee a las necesidades del parásito, como una relación de orden psíquico superindividual. El hecho es siempre el mismo : el insecto coloca sus hitevos en una parte de la planta - hoja o tallo - y, ante el estímulo de tal depósito, el vegetal reacciona con la producción de una stibstancía excitante del crecimiento đe los tejidos, una fitohormona, formando en torno del nido parasitario un sistema orgánico que aloja, preserva y alimenta a la larva hasta el fin del desarrollo del insecto, a menudo hasta la madurez alada. Las agallas son tan abundantes en la naturaleza que se calcula que existen diez mil clases distintaỉblioteca de Letras

Otro gể turaleza animada es el de la simpatía de las apariencias manifiesta en la estructura y coloración idénticas de animales y órganos vegetales, de suerte que el observador confunde fácilmente un insecto con una hoja, una rama, una flor o un fruto de la planta en que aquél habituaimente se posa. E1 caso más maravilloso es el de las langostas-hojas, pterocrozas y faneroptéridos, existente sólo en la región tropical de nuestro continente. No sólo imitan como "copistas perfectos"según expresa VIGNoN-, con "elegancia y elevada iniciativa artística" la apariencia de las hojas de los vegetales, desde las más frescas hasta las muertas, con todos los matices 
intermedios, sino que lugran remedar con detalles primorosos las diversas apariencias de distintas enfermedades y lesiones propias de tales partes de la planta, causadas por hongos, insectos y otros parásitos. El remedo no queda en la

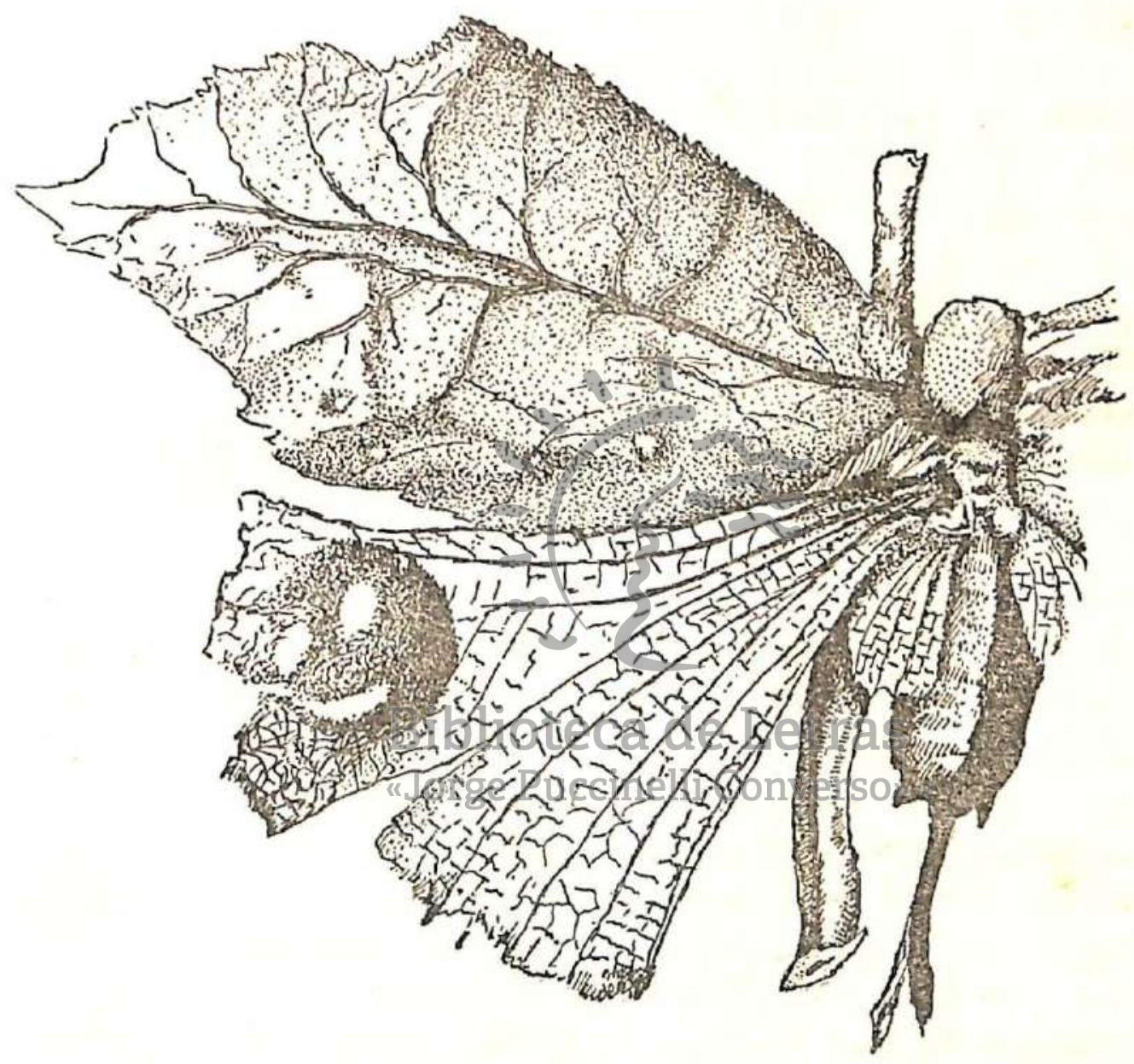

Fig. 2. Langosta-hoja, tanusia arrosa.

mera coloración, va hasta la producción de engrosamientos, adelgazamientos, perforaciones etc. de las alas de las langostas (Fig. 2). Tal forma de mimetismo - de índole semejante a la del camaleón, o mejor todavía de ciertos peces, que 
adquieren el mismo color (homocromia cambiante) y el mismo dibujo del medio en que se encuentran, y varian sincrónicamente con los cambios del mismo - fué interpretada por los darwinistas como resultado de la selección : los animales que "de manera fortuita" aparecen con semejante exterior, sobreviven y se multiplican porque les sirve de máscara protectora para no ser devorados por sus enemigos naturales, que así los confunden con las partes de las plantas con las cuales tienen parecido eventual. La experiencia, empero, ha demostrado la falacia đe esta explicación, pues los artrópodos de que tratamos se encuentran en el buche de los pájaros insectívoros con frecuencia proporcional a la distribución de los "enmascarados" en cada localidad. Los hechos llamados de mimetismo, además de mostrar los juegos artísticos de la naturaleza - más que su utilitarismo-, exteriorizan la unidad de sus manifestaciones expresivas en ambos reinos. Esto se patentiza con toda pureza en el caso de la "hoja errante", langosta de la India, idéntica a una hoja de árbol que incluso se agita y cae inerte al soplo del viento, pues su cuerpo seponeírígie enctua especiesde estado cataléptico (Fig. 3) "Serda prerificado doexistençia de restos fósiles de estas langostas en terrenos correspondientes a épocas geológicas anteriores a la aparición sobre la tierra de árboles con hojas que se les parezcan. Este hecho - como observa JoSEF SCHMID - constituye una evidencia en contra de las teorías utilitarias, tanto la lamarckiana de la imitación apetecida, cuanto la darwiniana de la selección natural de las variaciones al azar, ya que la "hoja errante" ha existido antes que las hojas arbóreas de aspecto similar. Ante evidencias de este género se siente la tentación de aceptar el pensamiento que PAul Valéry formula al estudiar las conchas : "Nuestra idea de lo útil, fuera del hombre y de su 


\section{$-37-$}

pequeña esfera intelectual, no tiene ningún sentido". Pero no se puede negar que hay casos de mimetismo realmente

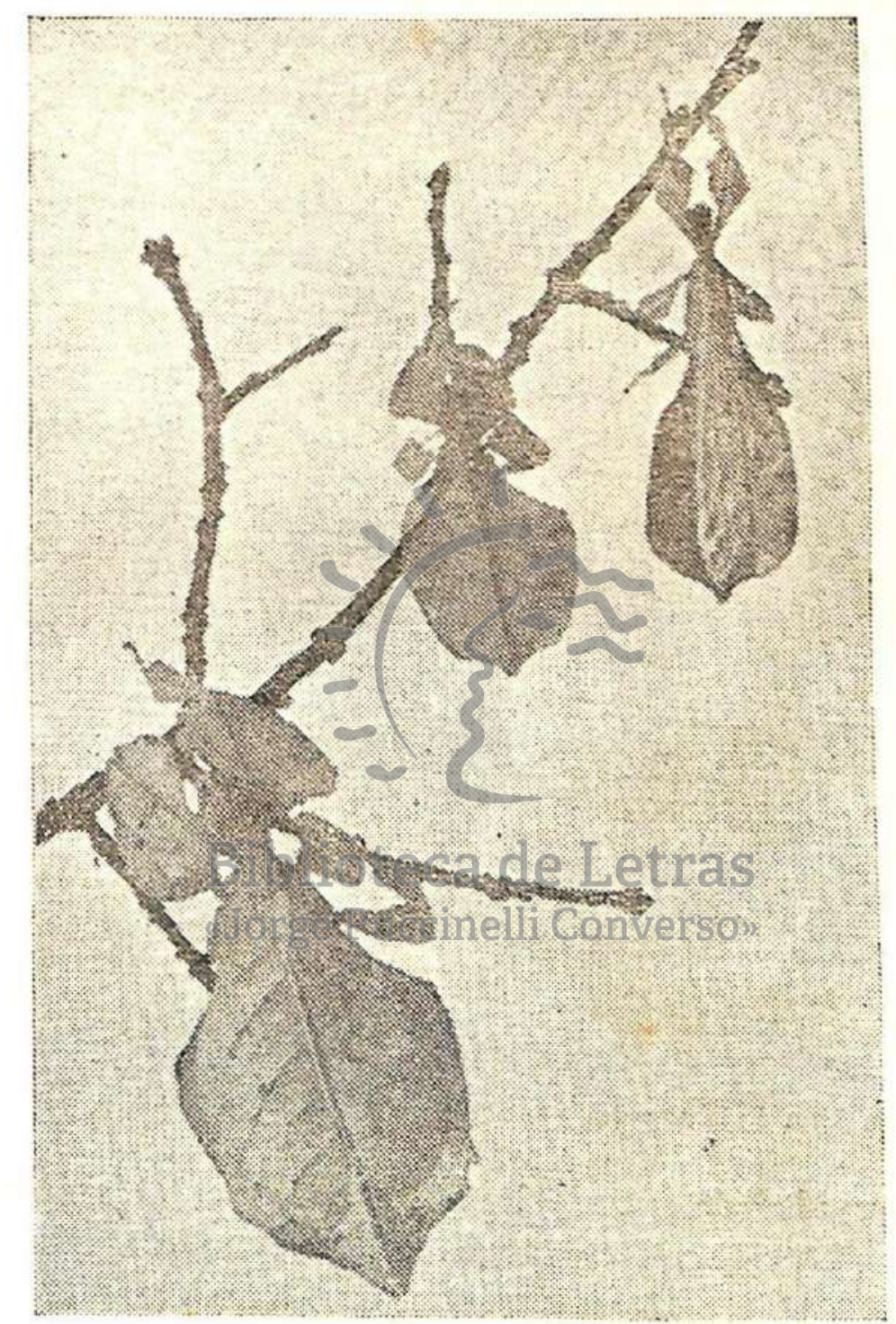

Fig. 3. Langosta "hoja errante".

ventajoso, como el de la mariposa kallima, de vivos colores, que "desaparece como por magia desde que se posa sobre 


\section{$-38-$}

cierto arbusto : oculta su cabeza y sus antenas entre sus alas, cuya cara inferior reproduce no solamente todas las nervaduras de las hojas del arbusto, sino hasta las manchas y cicatrices que hacen sobre las verdaderas hojas los hongos y los insectos", como en el caso de las langostas (Fig. 4).

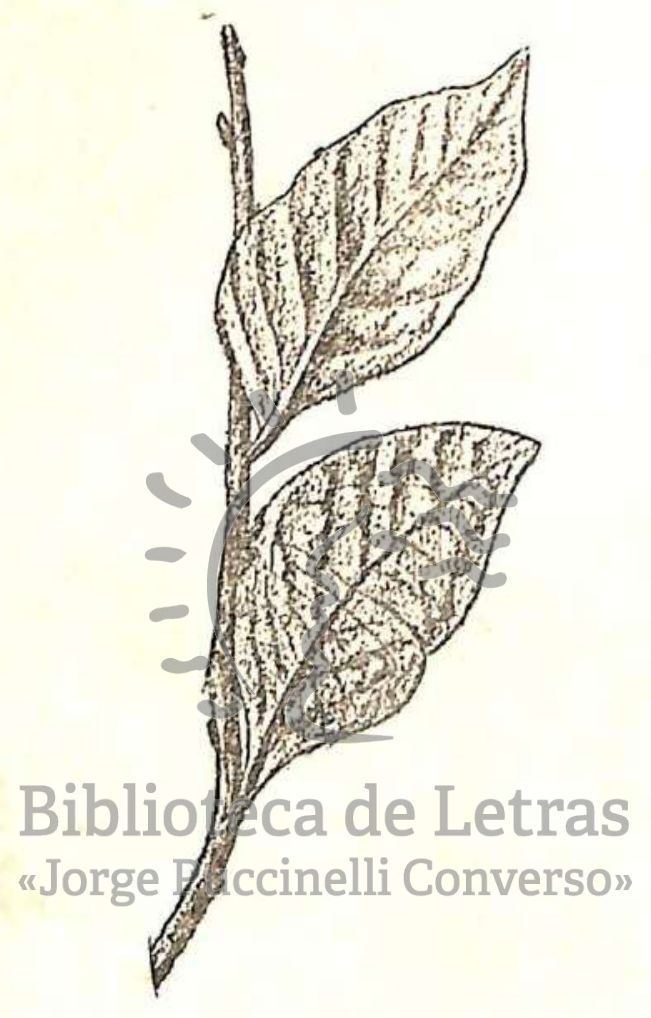

Fig. 4. Una hoja vegetal (arriba) y la mariposa kallima (abajo).

La. unidad de exteriorización complementaria entre animales y plantas, con teleología evidentemente ventajosa, se verifica en la estricta correlación existente entre la organización de las flores y sus visitantes : pájaros e insectos que a la vez viven del alimento que ellas les proporcionan y, como en pago, hacen posible su fecundación y multiplicación. Tal reciprocidad se cumple en forma óptima entre ciertas 


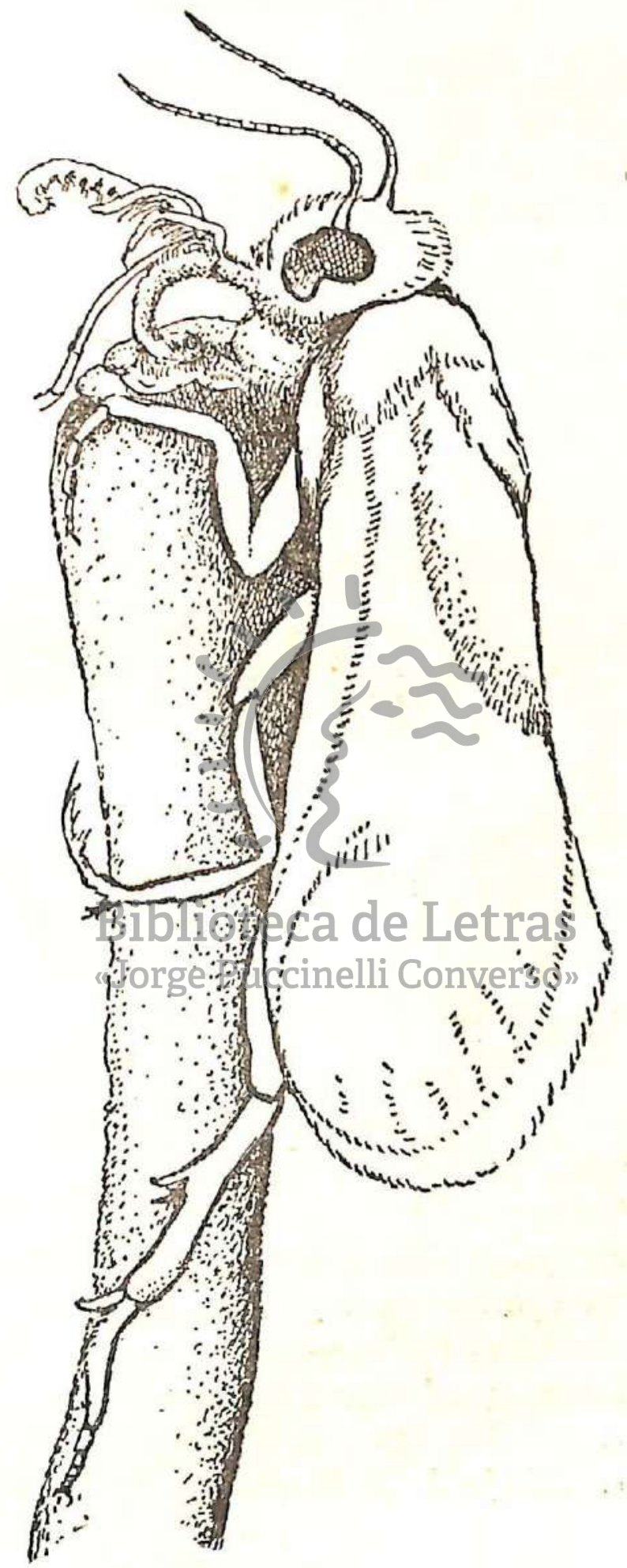

Fig. 5. La pronuba yuccasella se provee de polen (vista con aumento). 
plantas llamadas yuca (yucca filamentosa y $Y$. whipplei) y una polilla que es como el satélite indispensable de su ámbito vital, según descubrieron indepencliente y casi simultáneamente Zeller y Riley hace setenta años, en el curso de los cuales se han repetido las verificaciones confirmatorias. La pronuba yuccasella, como se llama la plateada polilla de nuestro ejemplo, apenas sale del estado de crisálida vive una exis-

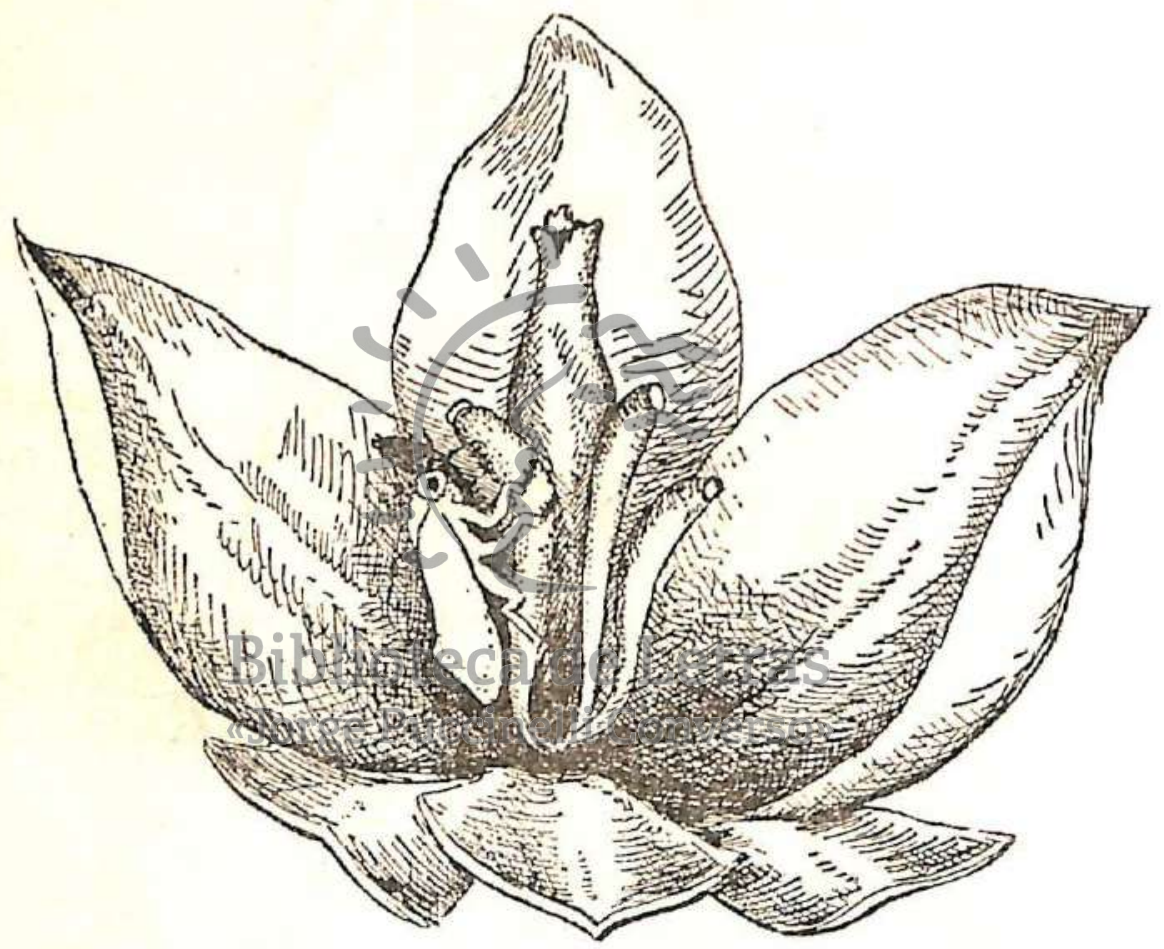

Fig. 6. La pronuba se dispone a poner en el ovario de la flor de yuca.

tencia efímera y sin alimentarse ya, y sin embargo se apresura a visitar una flor de la yuca - cacla flor se abre sólo durante una o pocas noches-, penetra en su interior, busca la antera, órgano productor del elemento sexual masculino, donde recoge el polen, hace con él una pildorilla que con suss palpos coloca debajo de su propia cabeza (Fig. 5). Ya con 
su carga fecundante al cuello, más grande que su cabeza, sale de esa flor y vuela a otra, en cuyo seno penetra buscando el órgano reproductor femenino, secciona el pistilo con el complicado instrumento de su oviscapto, de ordinario con-

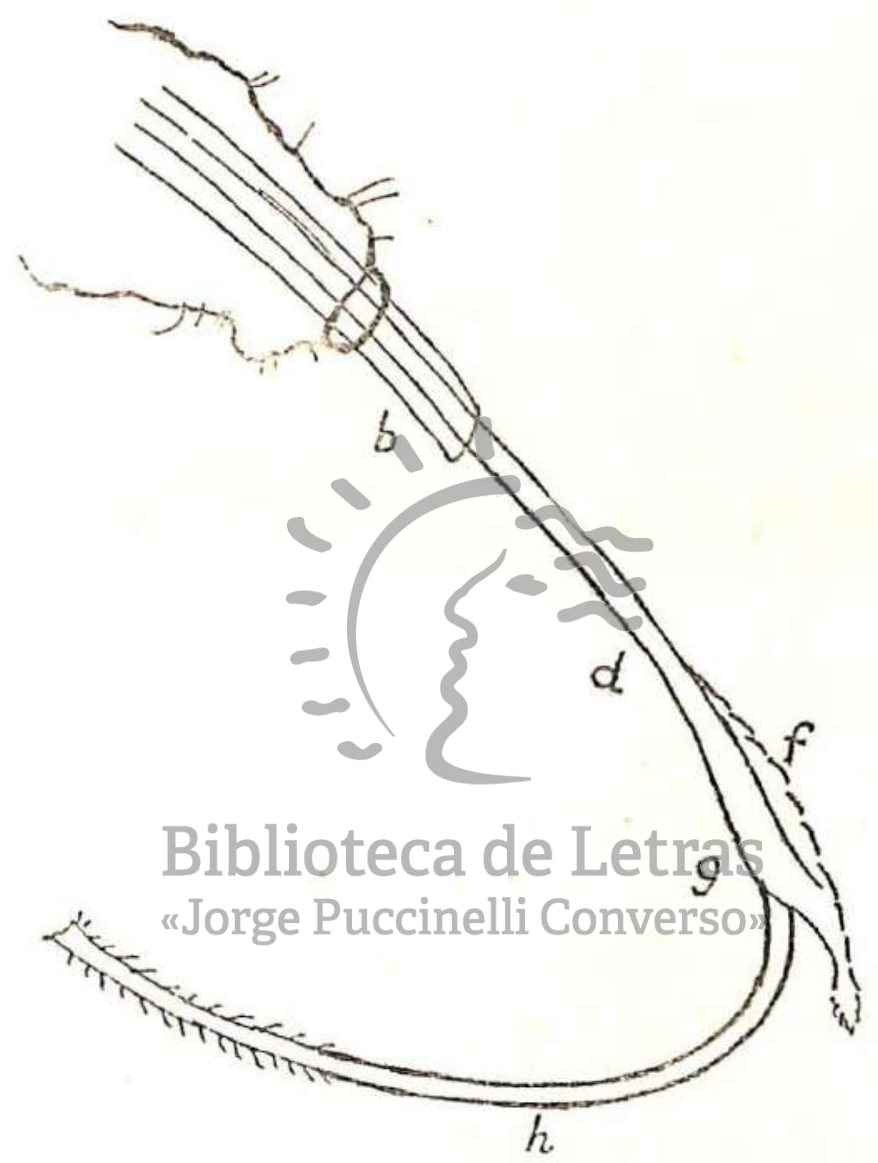

Fig. 7. El oviscapto de la pronuba, euya pieza terminal (h) es una finisima sierra.

traído y oculto en el abdomen, pone sus propios huevos entre los óvulos de la flor y, en fin, introduce el polen en la abertura que queda a descubierto por el corte dado (Figs. 6 y 7). Con esta compleja operación, que practica tres ve- 
ces en la misma flor, queda asegurada la fecundación de la planta y la viabilidad de la prole del insecto. En efecto, está demostrado experimentalmente que sin la mediación de la promuba quedaría infecunda la yuca, sin semillas, ya que de otra suerte es imposible que se realice la fecundación. Está igualmente demostrado que las laryas de esa polilla no pueden desarrollarse si no se alimentan exclusivamente de los óvulos fecundados de la yuca. Por último, cada una de las tres o cuatro larvas que se desarrollan en una flor sólo consume veinte de los doscientos óvulos que ésta posee, de modo que queda más de la mitad libre de daño y, por tanto, apta para llegar a convertirse en semilla. El parásito paga, pues, los servicios en provecho de su especie asegurando la fecundidad" de su huêsped. "Estas actividades maravillosamente adaptativas del instinto de la polilla de la yuca - comenta Llord MorgAN - son realizadas sólo una vez en su vida, y esa sin instrucción sin oportunidades de aprender por imitación y, aparentemente, sin previsión de lo que tendrá por consecuencia su conducta; pues no tiene experiencia del ulteriojidesting de los htuevos que pone $y$ no se le puede reconocer in conocimiento del efecto del polen sobre los óvulos".

Como no todo es harmonía en el mundo, ocurre que los individuos aplican el instinto desventajosamente para su especie. Una de tales aberraciones, en que el beneficiado indirectamente resulta el hombre, se observa en las relaciones entre una pequeña avispa y la higuera. Resumo la curiosa historia que refiere HYATT VERRILL: En 1880 una empresa importa a California catorce mil vástagos de higutera de Esmirna, famosa por la excelencia de sus frutos. Pasan los años, y las plantas, en lugar de dar higos, sólo presentan pequeños botones que caen antes de desarrollar. Ante este fra- 


\section{$-43-$}

caso, demostrativo de que las flores no son fecuncladas, se envía un entomólogo al lugar de origen de las plantas. Ahi los naturales le explican que para el logro de los frutos se requiere espantar a los malos espíritus con un procedimiento mágico especial. Este consiste en recoger los "frutos" de la higuera silvestre y ensartarlos en largos rosarios que después se cuelgan en las plantaciones de higuera doméstica. Tras pacicntes observaciones el entomólogo verifica que de los higos colgados salen unos insectos, los cuales se dirigen a los pequeños botones florales de los árboles vecinos, donde con gran empeño tratan de abrirse un camino por el estrecho orificio de la flor, y después de larga porfía - en que suelen destrozarse las alas - salen nuevamente, exhaustos, para morir luego. El proceso biológico consiste en lo siguiente : las avispillas al abandonar los higos silvestres en que se desarrollan, sacan de ellos el polen que llevan a los higos de Esmirna y así los fecundan, con lo cual la flor se convierte en fruto. El empeño infructuoso del insecto para penetrar al interior del higo de Esmirna se debe al instinto de poner ahí sus bübol, äteque no consigute Spues mientras que el higo silvestiferge Bastaintellabientoysapropiaclo para eso, el de Esmirna no lo es. El error del parásito - fatal para él y su especie y precioso para el hombre - está en confundir las flores de ambas higueras. Apenas es necesario agregar que el entomólogo đe la historia retorna a California provisto de los beneficiosos insectos, con cuya industria suicida se logra los magníficos frutos en la plantación hasta entonces estéril.

A propósito de los frutos, no deseo pasar la ocasión sin referirme a un hecho muy frecuente y al cual no se presta la atención que merece: la producción de frutos o de partes del fruto que son completamente inútiles para el vegetal 
mismo. En efecto, ¿para qué el pericarpio carnoso, por ejemplo, de una manzana, de un melocotón o de una ciruela? Y pasando a los animales ¿para qué las bellísimas pintas de la cola del pavo real, si ese animal (la hembra como el macho) es ciego para el azul? ¿Cuál es el fin práctico de la maravillosa coloración de las mariposas, ciegas para los colores? Es, pues, evidente que no todo es utilidad en el mundo orgánico, de la misma manera que no todo es lucha entre los animales : la ayuda, sobre todo entre los de la misma cspecie, es acaso tan frecuente como la pugna, especialmente entre los de especie distinta.

\section{Nanifestaciones psicoides on las plantas $\mathrm{y}$ en ol desarrollo corporal de los animales}

Al primer inwestigaror genal y empírico de los seres vivos, Aristóteless, se le mmpone la idea del alma como única manera legítima de comprender su estructura y sus manifestaciones. El análisis de la planta, del animal y del hombre le conducen a la concepción de tres clases de alma : la

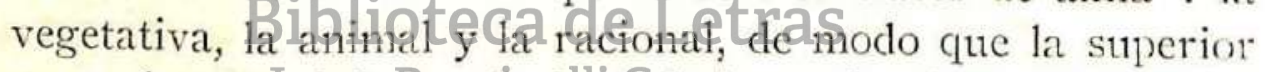

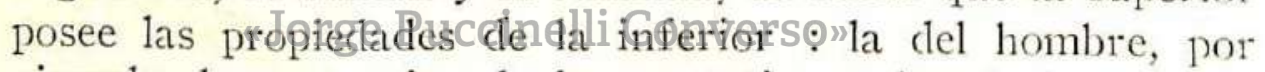
ejemplo, las potencias de la vegetativa y las de la animal. Aquí quiero referirme sólo al alma vegetativa, la cual rige la vida de la planta y el desarrollo orgánico del animal. Antes de considerar las ideas de Aristóteles acerca de este tema conviene recordar su punto de vista biológico general, pues los hechos de que trato en esta exposición se acomodan a él mejor que a ninguna otra teoría. Lo resumen admirablemente dos fragmentos de su obra De generatione animaliun, que reproduzco : "En las cosas de la naturaleza, conformes al orden y a la ley, las cosas individuales no poseen su carácter propio en virtud del hecho de haber tenido estas y aque- 
llas cualidades desde el principio, sino más bien manifiestan csas cualidades porque son específicamente tales como son. i:l origen $y$ el desarrollo es determinado por su esencia y en servicio de esa esencia : la esencia no depende del origen. Los antiguos filósofos de la naturaleza eran de la opinión opuesta, a causa de que no llegaron a reconocer que hay varias clases de causa : sólo conocieron la causa material y la causa cïiciente, y estas mismas no de acuerdo con su diferencia, y dejaron fuera de consideración las causas formal y final". "Inay algo que forma las partes, aunque no directamente como una entidad identificable, ni aún como si el desarrollo final fuese ya existente en él".

Respecto al alma, Aristétrites, en De anima, explana que ella es causa y principio del cuerpo vivo, según los tres modos de catrsalidad : es origen/de movimiento, es la finalictad del ser $y$ es la substancia formal del cuerpo. La palabra "vida" recibe varias asepciones, y basta que una de elias - la nutrición, por ejemplo, - se encuentre realizada en un sujeto para que se afirme que vive. Así son seres vivos los

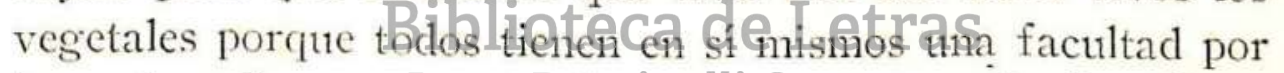

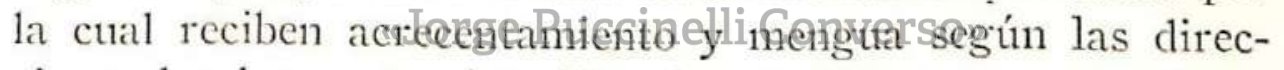
ciones locales contrarias. "La forma del ser en potencia es la entelequia... En efecto, de la misma manera que el intelecto actúa en vista de una cosa, así también actúa la naturaleza, siendo esta cosa su fin... Todos los cuerpos naturales (vivientes) son simples instrumentos del alma, tanto los de las plantas como los ce los animales : es, pues, que el alma es bien su fin. Se sabe que el término "fin" es tomado en sentido doble : de una parte, el fin mismo, y, de otra parte, el ser para quien este fin es un fin". Las plantas no poseen sino la facultad nutritiva; sus funciones son el uso de alimentos y la generación. La más natural de las funciones de 
una planta es crear otro ser semejante a ella, como el animal, otro animal de su especie, "de manera de participar en lo eterno y en lo divino, en la medida de lo posible". "Lo que pasa en las plantas, algunas de las cuales una vez divididas, manifiestamente siguen viviendo, bien que sus partes estén separadas unas de otras (lo cual implica que el alma que reside en ellas es, en cada plantạ, una en entelequia aunque múltiple en potencia), lo vemos producirse también, para otras diferencias del alma, en los insectos que han sido segmentados".

E1 concepto de entelequia, rehabilitado en la biología experimental de nuestros días por Driesch, en tanto que principio realizador de la finalidad inmaterial en la materia, contrapone la autonomía, la fecunclidad y el orden de lo orgánico a la pasividad de lo mecanico; significa que según una frase de Spengerer - " qa vida es la más necesaria y cumplida expresión de un alma" y no meramente la consecuencia de eventos físicos y químicos asociados por casualidad al enfriarse la Tierra. Es innegable que aun en el organismo vegetalisetproducer frenómenos que es muy difícil deslindarJđega marifestreciones ded nanimal, sobre todo del instinto, ya que "el problema de lo psíquico en general no se diferencia del problema de lo teleológico" (FRANCÉ). A estos fenómenos Bleuler los denomina "psicoides", y Pierre-Jean no vacila en incluirlos bajo la denominación de "psicología orgánica". No segụiremos en sus disquisiciones a estos discípulos de Aristóteles. Véamos los hechos que justifican la relación que trato de probar entre la ecología y la psicología. En primer lugar dos manifestaciones de las plantas, de las cuales una es como el duplicado del comportamiento de la convoluta y la otra resulta la contraria de la acción de la pronuba respecto de la intervención del ve- 
getal. La diatomea plcurosigma acstuarii se hunde en la arena de la orilla del mar cuando sube la marea, en el momento preciso para que las olas no puedan alcanzarla, ni más ni menos que el gusano convoluta roscoffensis. Las flores del agracejo, bcrberis vulgaris, tienen en su centro el pistilo, una pequeña columma que remata en forma de sombrero, y en torno de su base se extienden como radios seis estambres adosados a los pétalos, cada uno con đos bolsitas

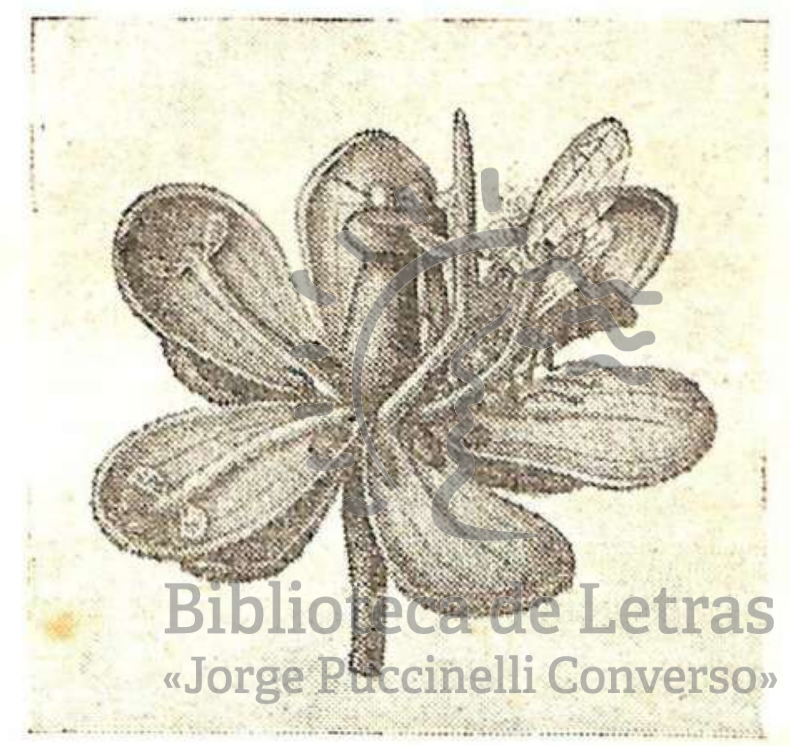

Fig. S. Flor de agracejo en el momento que des de sus estambres cubren de polen a un insecto.

cargadas de polen a los lados de su extremidad libre y dos depósitos llenos de visible y reluciente miel a los lados de la extremidad fija. Atraídos por este manjar tentador, los insectos se posan en la flor : apenas sus patas rozan uno de los estambres, éste se levanta, como movido por un resorte, y golpea la cabeza del intruso espolvoreándolo de su dorado polen (Fig. 8). "Es un espectáculo divertido reproducir. 
esta (catástrofe» - dice FrANCÉ - por medio de una puntat de aguja. El contacto más leve basta para que el estambre se levante precipitadamente. No existe en el mundo nada más sensible, salvo tal vez las pestañas de nuestros ojos. Y lo mismo que nuestro ojo se abre de nuevo tras la primera trepidación, el estambre recobra lentamente su posición de reposo, para alzarse aún inmediatamente después si viene al caso. Esta sensibiliclad tiene un fin especial... No hay medio más eficaz de hacer servir al visitador, que vience a regalarse con la miel, para el transporte del polen fecundante que espolvorearlo en la cabeza peluda. Y el enigma de la vida de las plantas se nos hace más impenctrable torivía, pues vemos su sensibilidad puesta al servicio de una organización cuyo espífitu nos es incomprensible. No hay otra parte sensible en todo el ramaje cel agracejo sino precisamente ahí donde tiene motivos de existir". En una serie de plantas de diversos géneros se presentan dispositivos con e! mismo fin de asegurar la fecundación y la multiplicacion de la especie, pero con medios diferentes, conforme a la estructura y las circintstancias adaticulares. Esste tipo de reacción de la planta "fepresentacifome diendichoo lo opuesto al de la yuca cuya fecundación se debe a la "iniciativa". y la industria de la pronuba. En el agracejo el insecto es el pasivo y la planta la activa, y como si obraran uno y otro - la pronuba y el agracejo - por instinto.

En efecto, un famoso botánico del siglo pasado, ANton Kerner Ritter von Marilaun, después de muchas y fecundas indagaciones, afirma que las plantas tienen instintos como los animales. Algunos investigadores modernos, entre los que se destaca HABERLAND, estudian diversas formas de sensibilidad (inclusive "visual"), de movimiento, de sueño, y complicados tropismos de los vegetales. Como quie-

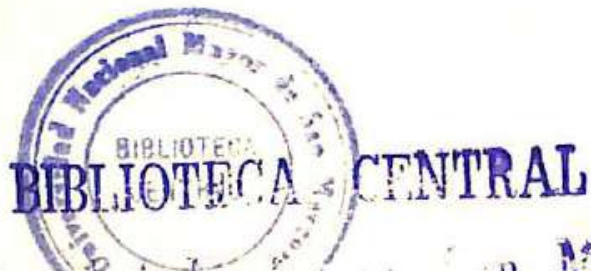


ra que Loes ha formulado una teoría físico-química de la vicla a base del tropismo, conviene recordar algunos hechos contrarios a esta concepción' mecanicista. Así, en muchas plantas el fototropismo cambia : con una ilıminación clébil es positivo, con una luz intensa se torna negativo y con una intermedia, es neutro. En la linaria cymbalaria, planta que vive adhericla a los muros, las ramas con flores se dirigen a la luz, lo que corresponde a la condición ecológica de este vegetal, "pero apenas sobreviene la fecundación y apenas tiene interés en volver sus propias ramas hacia el muro, đonde podrán crecer los granos, entonces interviene una inversión del movimiento : las ramas floriferas no se dirigen ya a la luz, sino que huyen de ella. En semejante caso la inversión es provocada por un hecho interior": (AcouA). Por otra parte, el geotropismo prorocado experimentalmente con aparatos giratorios, es positivo en las raíces mientras la centrifugación no es muy intensa; si se aumenta la velocidad de ésta, se convierte en francamente negativo, invirtiéndose el movimiento de la raíz. La investigación evidencia además que la nitovilidad de la raiz no se Teduce al geo-

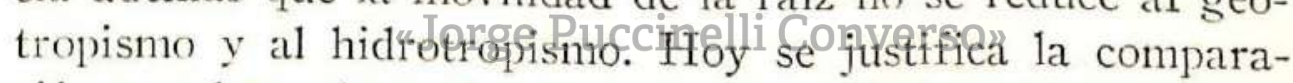
ción que hace Aristóteles de la raíz de las plantas con el cerebro de los animales, comparación que DARWIN repite al convencerse de la compleja dinámiça vital de estos órganns soterrados. Indiscutiblemente, el vegetal tiene manifestaciones psicoides. E1 modo certero como la drosera atrapa las moscas de que se alimenta o el cardo dipsacus laciniatus aprehende los insectos con cuya ingestión compensa el pobre pábulo que le ofrece el suelo de la estepa o, en fin, la $a l$ drovanda vesciculosa "pesca" crustáceos en el agua, no difiere esencialmente đel propio de, los carnívoros para apoderarse de su presa. Pero ningún ejemplo es más ilustrativo

\section{5}


a este respecto que el caso de la lathraea, pequeña planta que no sólo aprovecha para nutrirse el jugo de las raices de otros vegetales, a los quic asi stuele dar la muerte, sino que estí provista de verdaderas trampas para apoderarse de los animalillos, como "el asesino más pérfido que se ptucle representar la imaginación humana". Esta planta tiene en el ta1lo, ordinariamente sumido en el humus, tuna infinidad de hojas escamosas, uniclas unas a otras y que se extienden subterráneamente; cada tna encierra varias cavidades muy irregulares, comunicadas entre ellas, y provistas de aberturas hacia el exterior. En un ambiente donde pululan animalillos de mil clases, estas cuevas aparentemente inertes, ofrecen un refugio apetecible y muy engañoso a los habitantes del humus. Pues apenas uno de estos avanza al interior, cuando de las paredes próximas surgen, como manos ávidas, una multitud de prolongaciones vivas que apresan al incauto, lo digieren y desaparecen tan sigilosamente como surgieron.

En el desarrollo del organismo animal - y también en el vegetal Bjos fenémenosôturen-como si una finalidad

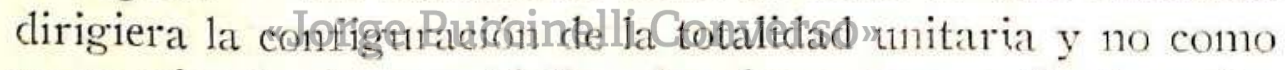
un mosaico donde se multiplican los elementos constitutivos. La embriología experimental, sobre todo gracias a Driescir y a Spemann, ofrece una serie de hechos reveladores de la índole psicoide del clesenvolvimiento individual. En el cmbrión hay campos formativos que determinan el desarrollo đe ciertas partes, pero en relación con los tejidos de la vecindad y el conjunto del organismo. Así, si en cierta fase del desenvolvimiento (gástrula) un trozo de los tejidos destinados a formar el cerebro se injerta en la parte que genera la piel, el trozo transplantado originará picl y no cerebro: las células se multiplican formando órganos en correspon- 
dencia con el nuevo campo en que se hallan y no en correspondencia con su propio origen. Lo mismo ocurre en fases más avanzadas: p. e., trozos que son el germen de órganos del tórax, injertados en la cabeza, contribuyen a formar la cabeza, y viceversa. Por otra parte, las células poseen y cribcrian futencias que sobrepasan las necesidades y que pueden manifestarse en la regeneración "rejuveneciente" aun en el organismo aclulto. Prueba de ello es que si a una salamandra se hace un corte cerca de la pierna, crece de la cicatriz una pierna supernumeraria. Mejor revela la influencia del campo local el experimento consistente en amputar una mano y un pie y transplantar los conos de regeneración de un munón al otro : el restiltado es que el cono tomado del muñón de la extremidad anterior e implantado en el de la posterior no forma una manp (conforme al destino nativo de sus células) sino un pie (conforme allugar en que crece), y viceversa. Por último, el organismo produce substancias que en condiciones normales impiden la aparición de nticvas formaciones. Por ejemplo, la retina y el iris poseen la aptitud de "inducir" ta formación de un cristalino si se les implanta en la epidermis, incluso despues que ha pasado la época de la formacion natural, del cristalino. En la retina persiste, pues, un "campo de cristalino", como reserva; por eso si en el tritón se impicle que se forme el cristalino por introducción del repliegue de la epiđermis (procedente del ectodermo), que es el verdadero origen del cristalino, entonces se forma éste a expensas del borde superior del iris, el cual procede de una hoja embrionaria completamente distinta (el mesoderimo). Este experimento de "heteroblastia" ya fué logrado por Gustay Wolfr, en 1894, como demostración de la "finalidad primaria" en la economía orgánica y, por tanto, como reducción al absurdo de la teoría darwinia- 
na. Hoy no se puede negar que el cuerpo del ser vivo se sirve, como la mente, de diversos medios para alcanzar el mismo fin. Innumerables hechos de esta clase condujeron a Claude Bernard a explicar los fenómenos fisiológicos como la manifestación de una "idea directriz", a PAULY a sostener una "psique del cuerpo" y a BLEULER, posteriormente, a la concepción de que lo psíquico no es sino la especialización de lo psicoide, cuyo dominio es todo el mundo de los seres organizados.

\section{Inmersión del animal en la estructura del mundo}

Al principio de este trabajo hemos examinado la adecuación de la materia a la vida. Ahora veremos la vinculación del animal con su ambiente tefurice, la inserción del ser vivo en su mundo, demostrativa de que uno y otro forman unidad grande e indisoluble, con un senticlo que trasciende toda relación meramente actual. Así, al aspecto estático de la comunidad de materia elemental se une el dinámico de la mutua compenetración. Con este propósito revisaremos al-

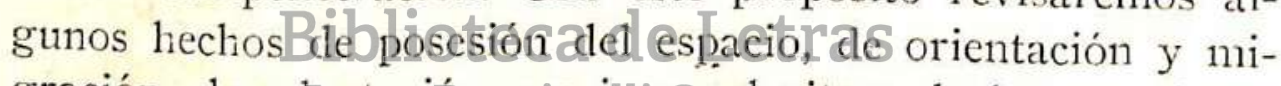
gración, de adlantaeióndulevisonra alv ritmo de las estaciones y a los requerimientos de los lugares. Con esto el lector verificará cómo tiene un sentido real el concepto antiguro del espíritu de las localidades, cómo - según la frase de JoseF SCHMID - " "un genins loci alienta y configura misteriosamente en la naturaleza".

La observación de los animales no deja ducla acerca de la existencia del instinto de propiedad. Todos pueden verificar que los perros, unos más otros menos, respetan el territorio donde los congéneres dejan la huella de su dominio; particularmente los mastines muestran una marcada tendencia a señalar su ámbito propio con la huella de su olor, 
que casi es tan respetable para los otros como si la demarcasen murallas. En los seres de mentalidad mucho menos desarrollada la cosa es también evidente. "Cuando dos gasteróstcos forman su nido en dos ángulos de un acuario, se traza a través del agua una línea invisible que establece los límites, separando los dos dominios individuales, y la, cual es defendida contra el vecino" (von Uexieuelt). En algunos animales el instinto de propiedad del espacio es periódico y relacionado con las necesidades no del individuo sino de la familia. Howard ha estudiado prolijamente el caso en las aves. En varias especies el macho se apodera clurante el período de la reproducción de un lugar de contornos rigurosamente determinados; ese será el terreno de producción de los alimentos requeridos para el sostén de la familia alada por formar. El apoderanínto es tanto más eficaz cuanto más precozmente es asegurado, pues strele suceder que circunstincias desfavorables obligan al píjaro a abandonar el habitáculo en busca de alimento en otra parte. HowARd insiste en que "los procesos son ordenados en el macho $y$ en la hembra de modsoque producen dun éfecto final : el nacimientos de los hijos en 131 tiempo defincido, óptimo. En la propiedad territorial adquirida, y exclusivamente dentro de ella, el ave ataca a todo macho de la misma especie. Sólo una vez que ha logrado señorear el terreno se aparea con la hembra. Durante el resto clel año los machos no son agresivos dentro de st1 propio territorio. Fuera de este, en todo tiempo, no se atacan : viven en harmónica comunidad.

En estos casos de animales con territorio propio los lugares son determinados con toda probabilidad por puntos de vista del animal : el acotamiento se basa en datos del olfato o de la vista. Pero en los insectos las cosas parecen ser muy diferentes, al menos para ciertas referencias al espa- 
cio. Es así que el retorno de las abejas a su colmena no depende de la percepción de ésta sino de la sitnación habitual de la entrada de la misma, pues no dan con ella al retornar si en su ausencia se ha cambiado de lugar la colmena, aumque sólo sea a dos metros de distancia del punto en que lit dejaron al salir. En efecto, se ve que se agolpan en el lugar del aire donde se encontraba la entrada de la colmena en el instante de su particla : no se trata pues de una localización relativa al panorama, sino que el espacio mismo tiene como una estructura accesible al insecto. La orientación en este tipo de casos se debe a lo que Hut. llama "gradiente de meta", de suerte que el animal se dirige hacia el lugar conocido pero no perceptible ni óptica, ni acústica ni químicamente, como si tuviese "el senticlo de la brújula" (BiERENS DE HAAN). Otra forma misteriosa de orientación se verifica en cliversâs clases de-insectos, nsada para co.municarse unos con otros. Así una falena macho se dirige con precisión matemática, atravesando de noche bosques y praderas, para retuirse a una hembra que acaba de salir de su cafbiliqienta cajadcerrada dentro de la habitación de una ciudał situasla a veinte onveinticinco kilómetros de distancia. Una hormiga necesitadą de ayuda para transportar un botín inesperado $\mathrm{y}$, aunque se halla completamente aislada de sus compañeras, no demora en recibir numerosas congéneres que concurren de diversos sitios, cada una por su cuenta. Un escarabajo hembra es encerrado en un sitio inaccesible, hace una serie de movimientos con sus antenas, y gracias a eso consigue que los machos se aproximen al lugar donde ella se encuentra y que se esfuercen en llegar lo más cerca posible; el entomólogo secciona una de las antenas de la hembra del experimento, y el fenómeno cambia: los machos no se dirigen todos al sitio más próximo, salvo 
uno, los otros se mueven inciertos; por último, el experinientador le secciona la otra antena, entonces la desorientación es general : los machos no se acercan sino cuando la hembrit ha sido colocada al alcance de sus sentidos ordinarios. HyatT Verkild, autor del experimento, asegura que tales escarabajos se commican por ondas como las de la radiotelefonía, y agrega que "se ha construído actualmente delicaclos receptores que captan y amplifican las ondas vibratorias enviadas por los insectos - aunque estas ondas sean, naturalmente, sin significación para nosotros". Entre estos insectos algunos exhiben en su dorso aparatos que no pueden ser sino antenas para semejante suerte de comunica-

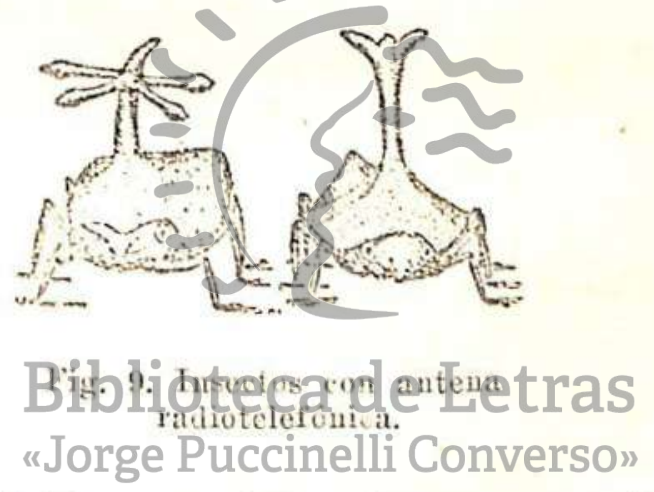

ción, recién adquirida por el hombre con medios artificiales (Fig. 9).

Tan desconcertantes como eso y todavía más difíciles de explicar son las migraciones de diversas especies de insectos. Entre la infinidad de observaciones inobjetables señalaremos el caso de las langostas del Africa. En la primavera se reunen en gran número y se lanzan en viaje hacia el norte, recorriendo innmensas distancias por encima del desierto, día y noche, desviadas a veces por los vientos, hasta llegar a Argelia y la costa del Mar Mediterráneo. Ahí se detienen y ponen sus huevos. Los indiyiduos de la nuteva generación, 


\section{$-5^{6}-$}

nacidos ahí y desconectados de los progenitores, cuando llegan a la edad apropiada se reunen, a su vez, y se dirigen con toda precisión al lugar del sur de donde partieron los padres, cuyo camino volverán a recorrer de retorno cuando sea la época de reproducirse, para hacerlo en el lugar de su nacimiento y después morir. Cosa semejante ocurre con mariposas, algunas de cuyas especies incluso atraviesan el Himalaya, otras el Océano Atlántico, del continente americano a las Islas Bermudas.

Con respecto a las aves, no vamos a recordar los inmensos periplos de sus migraciones espontáneas, en que recorren, literalnente, medio mundo, sino el caso del retorno al nido partiendo de dugares remotísimos desconocidos para ellas y sin ningún punto de referencia. Ruppel. hace coger 353 estorninos en un gran nimero de lugares de Alemania y los hace enviar a Berlín de la manera más rápida; los jone en libertad ahí y verifica que una parte retorna al lugar de origen, el mismo día cuando la distancia es de menos de $100 \mathrm{~km}$., el clía siguiente cuando es de 100 a $200 \mathrm{~km}$., el sub.

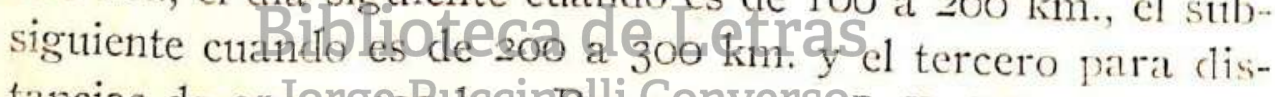

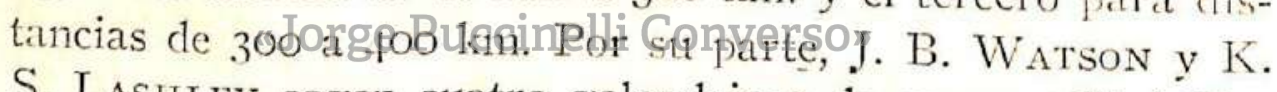
S. LASHLEY cogen cuatro golondrinas de mar en Bird Key (Tortugas) y las transportan encerradas en un butue a La Habana, a Io8 millas, en cuyo puerto las ponen en libertad. Al dia siguiente, después de haber pasado la mayor parte del tiempo en las proximidades de La Habana, se hallan de regreso en st nido. En otros experimentos streltan cinco aves de esta especie en el cabo Hatteras, cuya localictad jamás visitan, por ser Bird Key el límite norte de sus migraciones; regresan tres por lo menos a su hogar después de muy pocos dias, ya que tienen que recorrer sobre el mar una distancia de ochocientas cincuenta millas en territorio des- 


\section{$-57-$}

conocido (!). Otros investigadores llegan a resultados semejantes transportando aves encerradas en avión y a través de tierras y mares desconocidos. Ante estos hechos von Uexkuell sostiene que las aves poseen un espacio secundario de representación, cuyo punto central es su vivienda, además del espacio primario de percepción, en el cual ellas mismas constituyen el punto central rodeado de un horizonte. E1 espacio secundario no está circundado de horizonte, sino que puede extenderse ilimitadamente por todas partes, y carece de puntos de vista correspondientes a objetos accesibles a los sentidos y que pudieran servir de indicadores de? camino, sino que el espacio mismo debe formar una especie de gradiente.

Alguna analogía con la migración de los insectos y el retorno de las aves tienen los viajes de ciertos peces. A veces parten de las profundidades abismales del océano y, recorriendo mil, dos mil o tres mil millas, ascienden a elevados y remotos manantiales, a lagos de agua dulce, que visitan por primera y única vez en su vida, o a la inversa, descienden de las fuenteslidetos-áos al fondesle los mares,

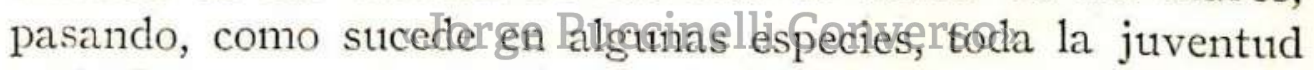
en la larga jornada de ida y toda la madurez en la de retorno hasta el lugar de origen, que casi siempre también es de fin.

Ejemplo clásico de la forma de emigración llamada catadrómica ofrece el ciclo vital de la anguila de agua dulce, anguila vulgaris de Europa. Las anguilas adultas, que pasan buena parte de su vida en lagos (donde se nutren y guardan reservas), en la primavera o a principios del verano abandonan, tras largo viaje fluvial, las corrientes de agua dulce, permaneciendo algunos meses en las zonas marinas próximas a las costas, primero muy al norte, en los mares 
de Suecia y Noruega, después, cada vez más al sur. Se las ha podido seguir con precisión hasta la altura de las Islas Azores. Es casi seguro que se dirigen hacia las Islas Bermudas, sin llegar a sus costas, profundizánclose, al fin, en las aguas del Atlántico. Parece que el desove tiene lıgar en los primeros meses de primavera, en las honduras del Atlántico, en una zona situada al noreste de las Bermudas, principalmente entre las longitudes $50^{\circ}$ y $70^{\circ}$. Las larvas se desarrollan en un año de viạje trasatlántico hacia el Viejo Continente, el que completan en dos años más, hasta 11cogar a las respectivas costas europeas. Las anguilas jóvenes, de tres años ya, se presentan en la primavera a lo largo de las costas occidentales de Furopa, y ascienden, en número incalculable, por los ríos. Lo mismo sucede - mutatis mutandis - con la anguila rostrated, con zona de desove también en el Atlántico, situada más aboeste que la de la europen, y los ríos cuya corriente remontan se hallan en la vertiente oriental de la América del Dorte. Se ha pretendido, con hipótesis poco sostenibles, explicar el movimiento migratorio de estos peces tomandgidinio bese das co frienteg marinas. Pero ninguna teoría mecanicistacipuerlecaçlakasoel problema ile su orientación certera hacia el agua dulce y su viaje contra la corriente de los ríos. Los mismos fisiólogos se declaran impotentes para resolver en los términos de su propia ciencia la conducta de la anguilas jóvenes en esta migración que reconocen que "es positiva y agresiva".

Caso típico y bien conocido cle la forma de migración de curso inverso al de las anguilas, anadrómico, es del salmón del Rin (salmo solar), cuyos huevos son depositados en noviembre y diciembre, en las frígidas aguas de los torrentes alpinos, conde se desenvuelven. Los pecesillos libres, en la primavera o el verano del año siguiente se diri- 
gen al Rin; ahí su piel cambia de color, circunstancia que parece hacerles insoportable la luz. En este estado, y presa de un hambre voraz, se dirigen a los abismos del Mar del Norte siguiendo el curso del río. En el mar encontrarán pábulo abundante y obscuriclad. Después de tres o cuatro años, en que alcanzan un desarrollo considerable, se encaminan de regreso a la desembocadura del mismo río. De marzo a agosto inician la travesia fluvial. Una vez en agua dulce, cambian totalmente sus costumbrres, a la inversa del descenso, de una manera particular en lo que a la nutrición se refiere: de glotones que son en el mar, pasan al ayuno absoluto. En esta condición hacen su larga travesía de retorno, río arriba, saltando los obstáculos que se les presentan. En este tiempo se desarrollan sus órganos de reproducción, a expensas de los otros tejidos de su cuerpo, que por eso y por el consumo de energías, el animal sufre una pérdida de peso considerable. El gasto de energías, por otra parte, se hace a expensas de las grasas y de las proteinas. En los torrentes de las montañas, la fuente natal, por pares, construyen sus nidos, desgran yefecundan. Los adultos que no mueren en la época nupcial viajan de nuevo al mar para allá rehacerse con la "abundante nutricion del medio pelágico. Este segundo viaje de la minoría sobreviviente es una excepción que parece propia de esta especie. En muchas otras especies de salmón del Atlántico y del Pacífico (de Europa, América y Asia) tienen lugar los demás procesos, con las consiguientes variaciones específicas. Es digno de mención el hecho de que todos estos peces al cambiar de medios tan diferentes desde el punto de vista físico-químico, como son el agua dulce y la de mar, pasan un período de transición en la zona próxima a la desembocadura de los ríos. Efectuando frecuentes idas y venidas entre el 
agua dulce y la salada, acaban por adaptarse y acostumbrarse a las condiciones de su nuevo habitat. Parece que el hanbre y la necesidad de alejarse de la luz contribuyen a promover el primer viaje, así como el impulso sexual y la atracción de la luz y del agua más oxigenada incitasen al segundo. Esto, naturalmente, no explica el complicado proceso que con razón se ha llamado "la novela del salmón". Como observa Russell, "estas migraciones de procreación tienen todas las apariencias de ser actividades dirigidas de largo alcance. Son actividades dirigidas al futuro : el pez busca decididamente una serie de condiciones que todavía no son presentes. Parece altamente inverosímil que su conducta al iniciar el viaje pueda ser explicada en términos de reacción a los estímulos inmediatos o presentes... La migración contra la corriente esencialmente es una actividad gobernada a lo largo del proceso y un esfuerzo persistente para alcanzar los lugares elevados apropiados para la procreación, esto es, un sitio favorable para el desarrollo y el crecimiento del pez joven".

En los pec̀es quque pasand todo sturciclo vital en el océano, se realizanj dambién desplazamientosomás o menos considerables para los fines del desove. Estas migraciones se efectúan en concordancia con las condiciones externas óptimas para la viabilidad de los individuos de la próxima generación y en circunstancias de tiempo, lugar, temperatura etc. verdaderamente ideales, como si fueran buscadas a medida de los requerimientos de la especie en cuestión. Uno de los casos más sorprendentes a este respecto es el de tna especie de esperlán, conocido en Cálifornia con el nombre de grunión, leuresthes temis, estudiacto por W. F. y J. B. Thompson. Durante las altas mareas de marzo a junio, se presentan tales peces en considerable número, formando 
verdaderas manchas, en las playạs arenosas de California. Esto tiene lugar durante la noche, cuando la luna llena determina muy altas mareas, saliendo el agua larga extensión en la costa. Es precisamente durante la hora u hora y media que sigue al máximum de la pleamar cuando los enjambres de peces avanzan y retroceden a lo largo de la playa. En tales circunstancias emerge en la cresta de çada ola co-

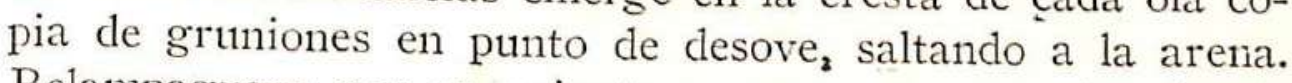
Relampaguean por un minuto sus cuerpos en quietud a la luz de la luna; en seguida se incorporan congruentemente en el agua, en el instante del reflujo. Se encuentran los peces desovando sobrepuestos o sepultados en la arena de la orilla, con la extremidad caudal hacia abajo, en las proximidades del límite extremo de altura arque ha llegado la pleamar. Las hembras ponen sus huevosen la arena, a cinco o siete centímetros de profundidac; y etando ellas agitan la arena mojada, el macho, que está cerca, en espera, procede a la fecundación, eliminando miriadas de espermatozoides en el agua. Todo el proceso del desove tiene lugar en el estrecho lapso de veintejaltreinta segundos. Der este modo se logra poner al hueys fectundado en las mejores condiciones para su desenvolvimiento, diríase para su incubación, pues el calor de la arena y su relativa sequedad - ya que sólo llegan a su altura las olas en el momento de la más alta márea - constituyen requisito indispensable. Además, de este modo están libres de los agentes de destrucción propios đel medio pelágico, para los que son muy vulnerables estos huevos y los pescadillos. Se realiza el desarrollo con presteza, de suerte que pasadas dos semanas, esto es, cuando precisamente tiene lugar la próxima marea de elevación máxima, que moja la zona de incubación, el embrión está listo para salir, y entonces rompe el cascarón, incorporándose al piélago 
por sus propios medios. Es digno de observarse el hecho de que entre las muchas especies de la familia a que pertenece el grunión, es la suya la única que realiza este ciclo vital con semejantes y peregrinas fases de calendario solar y lunar.

Lo que pasa con el grunión trae a la memoria el curioso

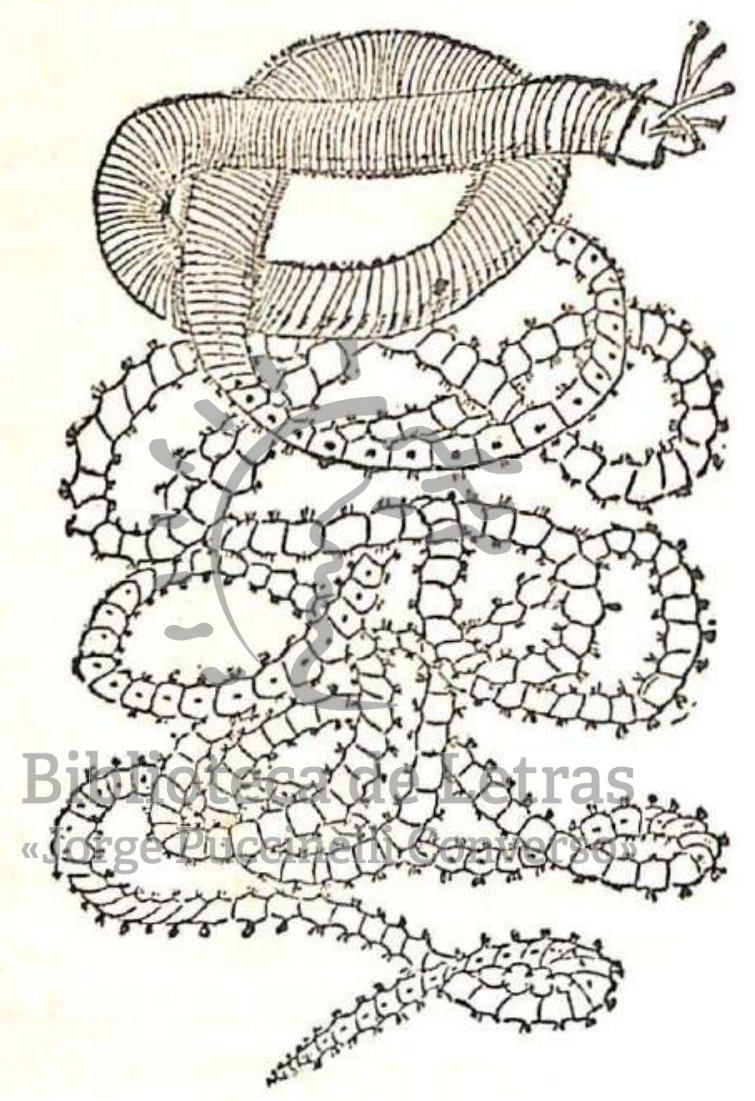

Fig. 10. El gusano del Palolo, eunice viridis.

fenómeno que ocurre en la vida de un invertebrado, fenómeno llamado del "palolo". Se trata de que un gusano marino, el eunice viridis (Fig. IO), cuyo habitáculo está en los bancos de coral del Mar del Sur. Se reproduce, precisamente, dos noches determinadas de la primavera, en octubre y 
noviembre, cuando tiene lugar el plenilunio. Entonces, y sólo entonces, el gusano se segmenta: su cabeza, đe color rojizo, queda fija en el banco de coral, mientras que la prolongada cola, azulada, se desprende, avanzando larga distancia en el mar, para realizar en la superficie el comercio de la fertilización. La cabeza regenera nueva cola, que se desprende al año siguiente. El palolo se observa también en las costas del Japón y en las de Florida.

La inclole de esta imponente serie de manifestaciones del preciso y previsor ajuste đel animal tanto al gran ámbito de los espacios telúricos, con la variedad de accidentes que van clescle las altas montañas hasta los abismos de los océanos, cuanto al ritmo de las estaciones y las fases de la Luna, es tan enigmática que no puede comprenderse sin aceptar una finalidad trascendente al individuo. Afirmar que el insecto, el ave o el pez se dirigen con empeño y seguridad al lugar, desconocido para ellos, donde sus padres se dirigieron es un hecho debido a tna especie de memoria de la especie, es explicar obcurum per obscurius. En contra de tal manera de ver Raj dosastseguede oponter atros hechos en cuya explicación noJ seguedecipetai Gotatenisteriosa memoria geográfica de la especie. Me refiero a hechos biológicos, a procesos orgánicos de previsión. Ninguno mejor que la época del celo y del parto en los mamíferos. Bien ha estudiado esto en los animales que interesan al cazador en Alemania. Demuestra que el momento del celo es del todo independiente de la temperatura, de la estación y de la existencia de abundantes alimentos, pues en los meses de mayo y junio, época de la vida fácil, no está en celo ni uno solo de dichos mamíferos en cuya especie las hembras conciben una vez al año. Por el contrario, la jabalina encela en diciembre, la zorra en febrero (a menudo la época de mayor penuria y 
frío), la gamuza, a fines de noviembre y principios de diciembre, cuando en su ambiente montañoso dominan las condiciones desfavorables; así, el celo parece presentarse sin regla. Pero si consideramos la época del parto, se revela de inmediato un orden bien fundado y como preestablecido. Los hijos nacen en el momento óptimo - la mayor parte en mayo y junio - para que puedan disfrutar del buen tiempo en su primer desarrollo. "La época del celo es, pues, exclusivamente reguladora de la prosperidad de la descendencia como de la conservación de la especie, que está por encima del individuo en toda la naturaleza". Pero hay hechos que tienen más importancia para mi argumento, por tratarse de la ađaptación certera a nuevos ritmos telúricos, tanto para el individuo cuanto para la especie. En los jardines zoológicos se ha observado que aves procedentes del hemisferio sur llevadas a Alemania y que se reproducen en la cautividad, conservan al principio su ritmo nativo del celo, funesto en el hemisferio norte, pues los hijos sucumben o sufren. Pero la mayor parte de las especies "aprenden" muy pronto a cam-

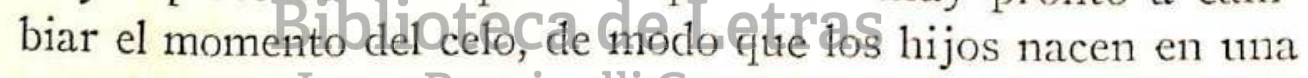

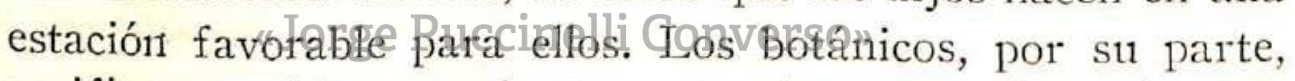
verifican cambios semejantes entre los vegetales. A este propósito apunta Pierre-Jean lo siguiente : "Amenazadas por el invierno precoz otras plantas salen de la dificultad de otra manera: se apresuran a florecer. Se ha sembrado al norte de la penínstula escandinava granos de cereales cosechados en Alemania y se ha visto, de año en año, madt1rar más y más pronto; al cabo de cinco años, bastaban yo clías en lugar de izo (Schuebeler). Un maíz de tierra cálida, cultivado en un país frío, ha sabido acortar a la mitad el tiempo de su evolución (Metzger). El frío no puede hacer crecer una planta más rápidamente ni madurar un gra- 


\section{$-65-$}

no más pronto". Este es el mejor argumento contra el mecanicismo y en favor de la ley de von BAER, según la cual jos organismos, y en general el conjunto de la vida, utilizan al máximum la materia y la energía.

\section{III instinto, en sentido lato}

Los datos precedentes muestran de manera inequívoca quue la vida instintiva del animal es inseparable de la bioesfera en su conjunto, con una coordinación precisa en el resazo realmente maternal de la naturaleza inanimada: la estructura estática y dinámica de la tierra, incluso la influencia del Sol y de la Luna. Ahora me propongo significar la iclea del instinto en su sentido más amplio, entendido como virtualidad conformadora del organismo, directora de la actividad del ser psicofisiológico y manantial de creación de la personaliclad espiritual.

Como vis sculptrix, el instinto es común a animales y vegetales y, conforme a loexpresado anteriormente, asimilable al "alma vegetativa" de Aristóteles. Una deformación del espiritu chentilite thecalentêdatpetensión de ex-

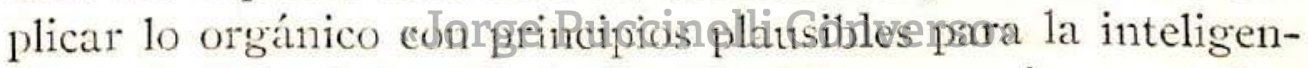
cia de lo inorgánico: la formación del cuerpo vivo como liecho de mecánica. Mas la empresa ha resultado frustránea. Ciertamente, se puede conocer más y más las condiciones y los fenómenos físicos y químicos del organismo formado y de su desarrollo. Pero lo esencial, la vida y el despliegute orgánico, como tales, no se acomodan a la misma medicia que la caída de la piedra o el funcionamiento del motor. Como ya lo sostuvo Aristótelis, el todo en el reino de lo orgánico es anterior a las partes, es conforme a plan, es regido por un fin. Este fin configurante, entelequia o razón creadora, es la verdadera causa final de la rnidad e histori- 
cidad de toda criatura; las partes materiales y las funciones son sus instrumentos. Solo con este criterio es comprensible el hecho de anticiparse la arquitectura de los elementos al fin de la función, observado en el desarrollo embriológico de todo ser vivo. Así como en el ojo del vertebrado lo que ha de constituir la retina nace de una prolongación del esbozo cerebral, los elementos formadores del cristalino proceden del tejiclo primitivo de la piel y las clemás partes tienen un origen diferente, en diversos momentos del desarrollo, en la génesis de todos los órganos del cuerpo se verifica igual colaboración plástica y "prospectiva", como no ocurre jamás en ningún sistema mecánico.

Instinto no es sólo el hambre y la sed, la necesidad de respirar, de moverse ete. Instinto es también, como vis sculptrix, la virtualidad que hade posible la formación del tubo digestivo (desde los dientes y, las glándulas salivares) el aparato respiratorio (con todos los reflejos que regulan su ritmo), el sistema motor (músculos, huesos, articulaciones y centros nerviosos de coordinación) etc. Aún más: como los órganos Bòlscịorina sỉn lentrodgel orclen monárqui-

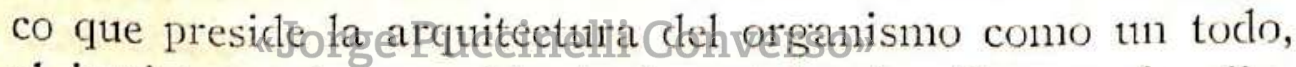
el instinto es inseparable de la entelequia. Con razón dice André Joussain, sigtiiendo a Bergson, que "el instinto prolonga el trabajo de organización: el esfuerzo por el cual el pollito rompe el cascarón, se libra de los residtuos y comienza a caminar, es una contintación del desarrollo por el cual sus órganos han sido configurados en el huevo". De otro modo es asimismo imposible explicar la perfecta especialización de la estructura de los seres vivos en harmonía con st ambiente propio. En muchos casos la adaptación de los sentidos del animal a lo indispensable de su mundo llega a la esquematización caricatural. Así las falenas que son víctimas 
de los murciélagos poseen un oído completamente sordo para todos los sonidos, salvo para el pío del perseguidor. La misma limitación ocurre en el olfato de la garrapata, que sólo es sensible al olor del ácido butírico, propio del sudor de los mamíferos de que es parásito. A esto llama von Uexkuell "exclusión de los efectos secundarios del mundo exterior de un animal", y advierte que es un recurso favorito de la naturaleza. De un modo general, como lo reconoce en el origen de las especies Cú́Not - sabio nada afecto a la metafísica-, hay una "preordinación que se revela desde el comienzo de una serie, y que conduce a la formación de órganos cuya finalidad es tan manifiesta como la de un ala de ave o de murciélago, de una glánđula mamaria de mamífero, de un órgano eléctrico del torpedo; lanortigénesis parece ser una telcogéncsis..." Esto equivale a aceptar una causa formalis intrínseca y su corolarig: "Fomis est prior in intentione, sed est posterior in crecutione" (SANTo Tomás DE Aguino).

De la misma manera que en la formación del organis-

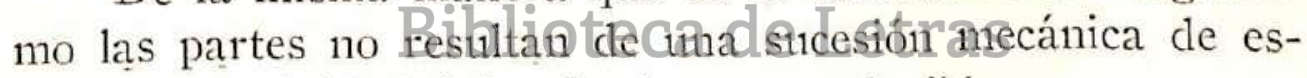
tados, la actividad Joelganîmatinel les Creduciblena puros cambios físico-químicos de las células, como si estas fueran aparatos que pasivamente se ponen en movimiento. Las células son ciertamente complicados instrumentos, vercladeros laboratorios, pero la economía de su diferenciación es secundaria al impulso unitario del conjunto. Las células, los tejidos y los órganos derivan de la actividad funcional. Ya hace un siglo Cuvier decía que "la vida es un torbellino más o menos rápido, más o menos complicado, cuya dirección es constante", y el naturalista darwiniano T. H. Huxuey comparaba las células con la configuración de la arena a orillas del océano producida por 
las mareas: en el símil las mareas representarían el flujo de la vida. Mas ello entraña un crror: iclentificar la actividad funcional con la vicla misma. Con esto afrontamos el punto relativo al instinto como vis directrix del ser psicofisiológico. La función ejercitada no es lo primario en la dinámica del organismo ni en la acción del individuo. Recuérdese la profunda idea aristotélica: "la esencia no depencle del origen": los estados iniciales y el desarrollo de los seres vivos son determinaclos por la esencia de los seres y son como son en cumplimiento de esa su esencia. Pero mejor que cualquier argumento, los experimentos de Albrecht Bethe y Wortas demuestran que la función ejercitada no es lo primero. El hecho es que quitando diverso número de extremidades al escarabajo vulgar, a las arañas y a otros animales, han podido verificar que a pérdicla se suple en seguida - salvo raros ea os ef que demora algunas horas - por movimientos que permiten avanzar al animal hacia adelante. Tal persistencia del movimiento bien dirigido sólo puede efectuarse cuando las restantes extremidades cambian el tipo de su movimiento, tanto en el ritmo como en la direc-.

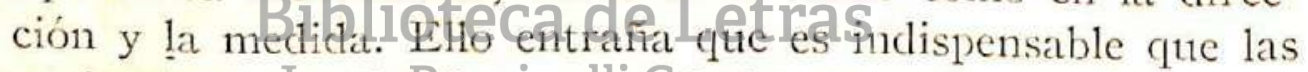

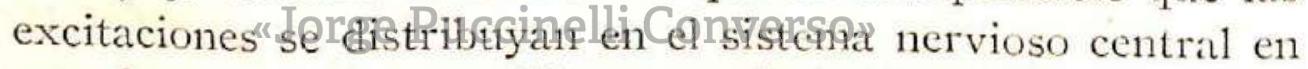
una forma totalmente diferente a la habitual. En otros términos: los centros nerviosos tienen que cambiar sus funciones después de cada amptatación de un miembro o intervención análoga. Si no fuese así, los animales operados deberían exhibir la marcha en círculo, la caída o el paso lateral después de las amputaciones asimétricas, y la pérdida del paso - mas no el cambio de ritmo etc. - en el caso de las amputaciones simétricas. Cadá amputación de uno o varios miembros conduce, ptues, a un ntievo tipo de coordinación, absolutamente original, ya que es tan grande el núme- 
ro de combinaciones posibles, que ni siquiera cabe pensar que estuvieran inscritas de antemano todas en el sistema nervioso. Este número de combinaciones posibles sería de doscientos treintitres en la araña (!). Además, cuando la araña zancuda es privada cle todas sus patas, utiliza, para suplirlas, ciertas extremidades ajenas a las funciones locomotrices, que jamás en condiciones normales se ponen en contacto con el suelo, esto es, los palpos mandibulares. Es digno de notarse que la fijación de una pata al cuerpo no tiene ni remotamente los efectos de la amputación. Más sorprendente es que extirpando en el escarabajo acuático el ganglio esofágico superior antes de amputar las extremidades, el cambio de función locomotriz se realiza también con sentido, congruente y prontamente. Hasta cuando se extirpa el ganglio esofágico inferion-que tiene fal vez funciones análogas a las de medula obligada - se manifiestan los esfuerzos funcionales adecuados. Infestigaciones ulteriores de BETHE en perros mutilades accilentalmente y en perros cuyos músctilos de la locomoción se conectan por medio de operaciones quirúrgicas con nervios correspondientes a ór-

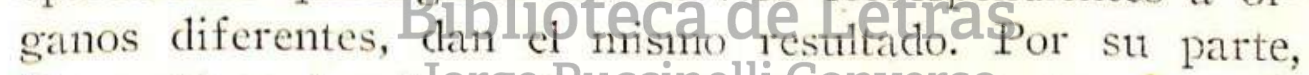

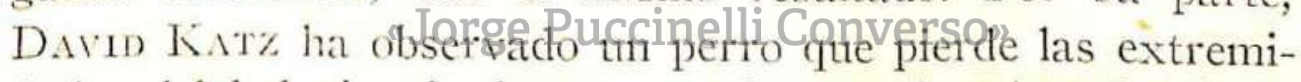
dades del laclo izquierdo y antes de que cicatricen las heridas aprende a caminar con sólo las dos extremidades del lado derecho. También yo he tenido ocasión de verificar cosa semejante en un perro de los alrededores de Lima, cuyo tren posterior queda paralítico a causa del traumatismo produciclo por un automóvil. Pocos días después del accidente, el animal aprende espontáneamente a marchar con las dos extremidades anteriores (llevando unidas al abdomen las posteriores) con perfecto equilibrio y compás de bípedo o pedímano. Todo esto lleva al convencimiento de que las excita- 
ciones que en la locomoción de un animal llegan a los músculos de sus extremidades, no se regulan invariablemente como en un esquema anatómico ni constituye tampoco mecanismos funcionales primarios, sino que su fuerza, su dirección y su continuidad se determinan por la vis directrix supraordenaclora, según las necesidades y circunstancias de cada momento.

Por último, como vis creatrix, el instinto constituye fuente de originalidad espiritual. En este sentido, el genio, la inspiración y todo aquello que el ejercicio no puede sino facilitar, disciplinar o perfeccionar, pertenecen al reino del instinto, en la acepción amplia que le doy.

Semejante extensión del concepto - instinto como potencia organizadora, difectiva y creadora - no es arbitraria, pues una y la misma leyerige la arquitectura de la naturaleza, da sentido a la economía de la biosfera y unidad al ser psicofísico individulal, aunque el margen de libertad vaya en aumento de uno a atro extremo y aunque la esencia de cada ser y el plano de diferentes virtualidades se revelen de

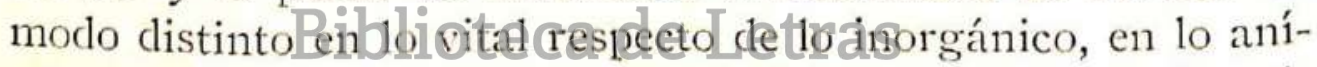
mico respecto dorlevitaldy enllocespititulah respecto de lo anímico. Asi, pues, aunque situlados en la misma clirección ascendente, la embriogénesis, la coordinación psicofisiológica, el instinto en senticlo estricto y la invención espiritual no son fenómenos iclénticos.

\section{El instinto, en sentido estricto}

El instinto sensu stricto ptede definirse como la potencia psíquica por cuya virtud el animal aprehende espontáneamente la realidad de su munclo y actúa sobre ella de modo oportuno, adecuado, cabal y específico, conforme a determinados fines, en servicio propio, de la especie o de otros 
seres vivos, sin previsión consciente de tales fines y de las consecuencias de la acción. Analicemos nuestra definición para mejor fundarla.

El instinto es potencia psíquica en el sentido de que constituye un principio dinámico rector o fuerza que desarrolla y clirige tna estructura anímica; no como mero vector físico, pues no se trata sólo de intensidades sino también de condiciones cualitatiramente originales, que marcan un rumbo y excluyen todo lo que a él se opone. Si se tratara de un vector físico, las hembras de las mariposas, por ejemplo, pondrían sus huevos en la primera hoja que se les presentase y no escogerían, al ofrecérseles varias de diversos vegetales, aquella que sirve precisamente de substancia nutritiva óptima para sus orugas. Asimismo, la avispa filanto si no obrase según una dirección selectiva, con fin específico, cuando coge una abeja doméstica provista del néctar de las flores, para llevarla conto alimento para sus hijos, no se cuidaría de eliminar del cuerpo de la presa, con minuciosa escrupulosidad, todo rastro de miel, que es veneno mortal para sus larvas. Biblioteca de Letras

El instinto es Jmanifestaciónllespontáneao ya que no se halla sujeto a imposiciones o rectificaciones procedentes de fuera. Innato, se desenvuelve integramente y con perfección descle la primera vez que se realiza, y si se repite no es de manera mecánica e invariable, pues el modo de obrar varía en algo de una a otra ejecución: este cambio se llama la "mađuración del instinto" cuando entraña mayor esmero. Además, insectos de especies muy próximas, al extremo de prestarse a confusión por su forma y los detalles de su organización, tienen "costumbres" y realizan obras totalmente diferentes. Por otra parte, todas las telas que teje una araña o los nidos que construye un ave corresponden al mismo prin- 
cipio, a la misma idea arquitectónica, pero cada tela o cada nido es original y congruente con la situación concreta, no es estereotipado y sin expresión de iniciativa como el producto de las máquinas. En fin, el mismo tipo de actividades instintivas, incluso muy complicadas, se presenta en animales de diverso género. Así la peregrina práctica de cultivar plantaciones de hongos se ha verificado tanto en varias especies de hormigas y termites cuanto entre las de coleópteros. Es tan especial y sorprendente esta muestra del instinto que vale la pena trasuntar las observaciones hechas por voN IHERING en las hormigas. Al emprender su vuelo mupral, la reina de la colonia lleya en la boca, se diría como dote, cierta cantidad de semillas de un hongo determinado. Con esta provisión, una vez fecundacla, tareina y sus obreras siembran cuidadosamente un huerto y to abonan con sus propios excrementos. Previamente, el hterto, de ordinario subteráneo, ha siclo convenientemente preparado, pues el terreno de cultivo está constituido por las hojas de determinada especie vegetal $\mathrm{Al}$ efecto las hormigas buscan estas plan-

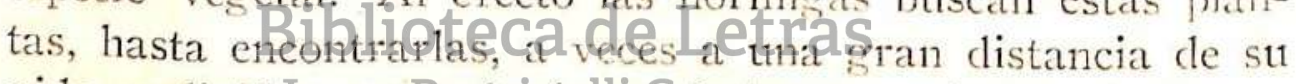

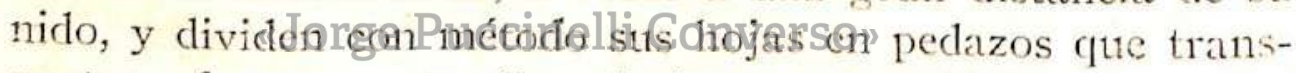
portan afanosamente. Cuando las esporas del hongo - que también es de una especie perfectamente seleccionada - han germinado y se desarrolla la parte vegetativa de la planta minúscula, las hormigas cuidan de levantar las hebras con stts mandíbulas, de modo que crezcan bien las partes tuberosas cargadas de substancias nutritivas. Naturalmente, en el huerto crecen "malas hicrbas", pero las obreras las extirpan con sin igual eficacia. El instinto de las hormigas consigue a la perfección cultivos puros de la especie determinada, la única que conviene a su alimentación exclusiva. Esta pureza de los cultivos de hongos ha sido lograda muy penosa- 
mente, y no siempre, por el hombre de çiencia, después de infinitos tanteos y usando los grandes recursos de la técnica de laboratorio. *

El instinto apareja la aprehensión de la realidad circundante y la acción oportuna y adecuada del animal. Se trata de una aprehensión circunstancial, según los apremios de la espontaneidad emergente y se refiere a lo que revela posibilidades vitales, resistencias, atracciones y repulsiones primarias; es típicamente un captar de exteriorizaciones ajenas, de intenciones de otros seres, que orientan la reacción de modo inmediato. E1 mundo, según la disposición de cada animal, es un campo de expresiôn animada, como para el hombre es la apariencia del próiimo, en especial el semblante: fuente fisonómica de comminicación que ante todo aproxima o aleja, que granjea un asociado o pone en guardia frente a un contrincante, sin que intervenga ni la experiencia ni la crítica. La aprehensión instintiva está íntimamente ligada a la acción del momento, es ya movimiento naciente, eficaz o fallido. La inserción del animal en la bioesfera, aunque estrecha por-sulfatea cle capacifad pata el conoci-

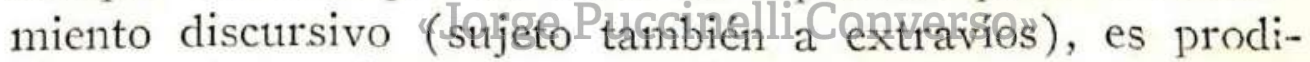
giosamente aguda para captar lo concerniente a sth actividad en la situación particular. E1 animal obra con "actos industriales" - como dice con toda justeza FABRE-, reveladores con frecuencia de una sabiduría que desborda las

* Los cultivos de hongos requieren cierto grado de humedad, mantenida de manera a veces sorprendente por los animales. Así, según Eugen N. Marais, los termites que habitan en terrenos secos y ealcinados hacen perforaciones profundísimas, hasta de más de 20 metros, para proveerse de las corrientes subterráneas con un personal activísimo de verdaderos aguadores profesionales. Es digno de notarse que la immersión de los termites en la estruetura del munclo no sólo se manifiesta en el acierto de buscar el líquido en el seno de la tierra, sino en la orientación del túnel que construyen, el cual corresponde a una línea en zigzag en el plano de este a oeste y nunea en dirección de norte a sur, como si los insectos construyesen su pozo con indicaciones semejantes a las que el hombre logra con la brújula. 
posibilidades humanas de explicación. A los numerosos y excelentes ejemplos que nos ofrecen los Souvenirs entomologiques de FABRE (que ningún hombre culto đebería ignorar) preferimos uno debido a la observación de R. W. G. Hingston, que ratifica, no sin rectificaciones de deta1le, las observaciones más discutidas del gran naturalista francés relativas a la ciencia consumada de los insectos cirujanos anestesistas que paralizan a su víctima con el fin de conservar vivo e incorruptible el alimento destinado a sus descendientes. Hingston ha observado repetidas veces en los alrededores desérticos de Bagdad la lucha de la avispa salvaje cryptocheilus rubellus, digno émulo de los magos y efrits de Las mil y ma waches, con una tarántula. Esta araña venenosa vive en el fondo de un tunel producto de su industria. La avispa busca a la tarántula haciéndose un camino en torno del escondite de ésta, la ataca por detrás, obligándola a salir. Durante un tiempo le da golpes con su dardo, dirigidos al gran vientre de la araña. Después de ha-

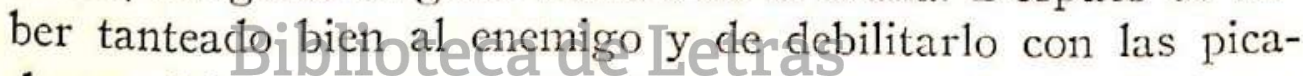
duras abdomjinales, emprende un ataquie a fondo. Se lanza sobre la tarántula, prendiéndose de la parte posterior para evitar las terribles mandíbulas de ésta, aplica su propio abdomen de través al torax de la víctima y se dedica a buscar đónde debe dar el golpe decisivo; cuando lo encuentra, introduce la punta de su abdomen entre la unión del segundo y el tercer par de patas, donde precisamente se halla el punto de penetración adectrado hacia el nudo vital de la víctima: ahí clava profunda y certeramente el dardo que emponzoña el ganglio nervioso motor (Fig. II). Con esto la peligrosa tarántula queda incapaz de todo movimiento, a merced de su enemigo. Debe advertirse que la avispa no intenta clavar su estilete sino donde está el ganglio, después 
de buscar cuidadosamente la única vía posible. Para orientarse "la avispa se guía, no por la constitución exterior, sino por la anatomía interna de su víctima".

Por último, el instinto se endereza misteriosamente en servicio de los fines propios del individuo, de la especie o de alguna manifestación de la vida, sin que generalmente el animal conozca las consecuencias de sus actos. En efecto, la conducta instintiva condiciona a menudo el albergue, la nutrición y la defensa de seres que el sujeto no conocerá jamás. El animal procede con previsión en apariencia clarividente de series complejas de acontecimientos que ni él ni

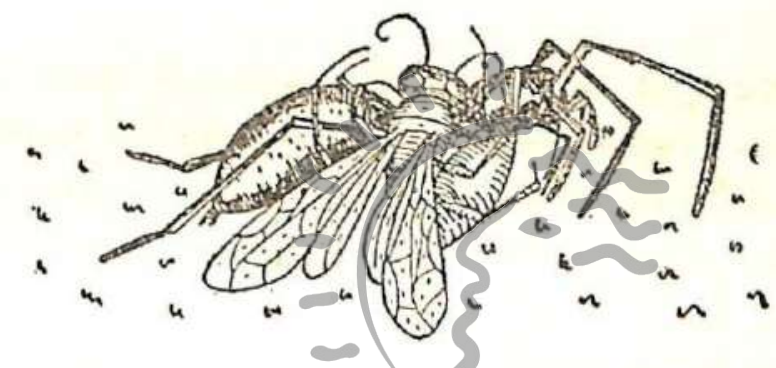

Fig. 11. El chryptocheilus rubellus paraliza a una tarántula de vientre negro.

ninguno de sus antecesores ha podido presenciar. Es asunto discutido si los animales proceden con conciencia o conocimiento en la realización de sus operaciones instintivas. CUVIER, hace cien años, asimilaba el instinto al estado extraconsciente del sonámbulo: "No es posible hacerse una representación más clara del instinto - escribe - que suponiendo que los animales tienen en su sensorio imágenes y sensaciones congénitas y firmes que los determinan para la acción; es una especie de sueño o visión lo que prosiguen de modo consistente, y se les puede considerar como sonámbulos en lo que se refiere a su instinto". El filósofo KI.AGES propugna hoy ideas afines a las de Cuvier. Para FAbre el 
instinto es ciego, inflexible, inconsciente. Por otra parte, no faltan los defensores de la tesis contraria. Ya Condillac afirmaba que "el instinto no es nada o es un comienzo de conocimiento". Un investigador contemporáneo, Тномas, se esfuerza por demostrar experimentalmente que el instinto entraña conocimiento. Se basa sobre todo en la variedad de procedimientos y modos que siguen los individuos para alcanzar el mismo fin, y en la índole previsible de los fines. Según él, los animales tendrían "una noción precisa del fin que debe realizar su actividad" y define el instinto como "el conocimiento virtual y hereditario de un plan de vida específico".

Me parece que nolse debe pretender una solución en masa del difícil problema. La yariedad de las formas de ejecución y la conformidad a plan de los actos instintivos pueden ser tan faltas de conocimiento como la diferencia de procedimientos en la formación o funcionamiento de los órganos corporales. Sin embargo ningún embriólogo y ningún fisiólogo pretende que el organismo tiene conciencia o conocimiento de syiforrinacióna de sư funcionamiento. Se puede sostener, emper g que algungscactosribstintivos se prestan a ser interpretados como que entrañan cierta virtud cognoscitiva e incluso algo comparable a la libertad de acción: una percepción inmediata de bienes que atraen y de males que repelen, así como la capacidad de elegir un camino o una operación entre varios posibles. El caballo que huye aterrorizado ante el tigre que encuentra por primera vez en su vida, innegablemente tiene la aprehensión inmediata de que está en peligro. Un ejemplo mejor: el solifugo galoedes arabs, mucho menos fuerte que su enemigo el escorpión, dueño éste de diversas armas, una de las cuales particularmente temible, no obstante que se enfrenta con él por primera vez, tiene proce- 
dimientos eficaces que no pueden haber sido aprendidos gradualmente por sus antecesores, pues no empleados todos y con perfección determinarían la muerte segura del solífugo. En la lucha éste procede como si conociera perfectamente las armas y la energía del escorpión. Una vez frente a frente, ambos preparan sus órganoş đe combate: el alacrán se lanza con sus pinzas abiertas y con el aguijón erguido, el solífugo para los golpes manejando con destreza sus palpos proyectados. Después de una serie de escaramuzas llenas de prudencia, el solífugo apela a la estrategia: gira en torno del alacrán y concentra su atención, como quien se ha señalado un objetivo, en el aguijón caudal de su enemigo. Aunque tiembla, lleno de terror, en cada momento quiere saltar. sin decidirse, hasta que llega el momento heroico: da un salto terrible y con agilidad y Iuerza inauditas se prende de la cola del escorpión, justamente por debajo de la ampolla venenosa, y con sus dientes acaba por romper la cola, inutilizando el arma más temible del adversario, quien con ello pierde la partida (Fig. I2) Como el caballo aprehende que el tigre es una amenaza, así el solífugo ve en el aguijón el ar-

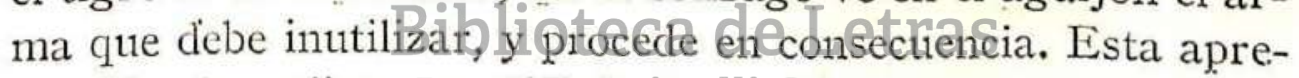
hensión inmediatar Jesgdificitcdeeltédircirversta categoría de conocimiento en la acepción ordinaria. El instinto denota conocimiento virtual en el sentido de que su desarrollo interno, como sucesión de actos psíquicos, es un proceso en marcha que tiene su razón de ser en su cumplimiento. Es un avanzar en lo dado siguiendo, con las transiciones, la atracción de una imagen presentida de la naturaleza de las cosas. Más difícil todavía es interpretar la "ciencia" misteriosa de los insectos cirujanos anestesistas. Lo que sí puede afirmarse con certeza es que la aplicación de los recursos, en el combate, por ejemplo, corresponde a intenciones del animal, 
por lo menos en parte - de ningún modo son maquinales, como afirmaba Descartes de toda la actividad del animal y como tođavía sostienen sus secuaces los materialistas que pretenden explicar los instintos como una especie de fisiología mecánica de reflejos y de hormonas, olvidando que el instinto se manifiesta incluso sutil en los animales que carecen de sistema nervioso y de glándulas de secreción interna.

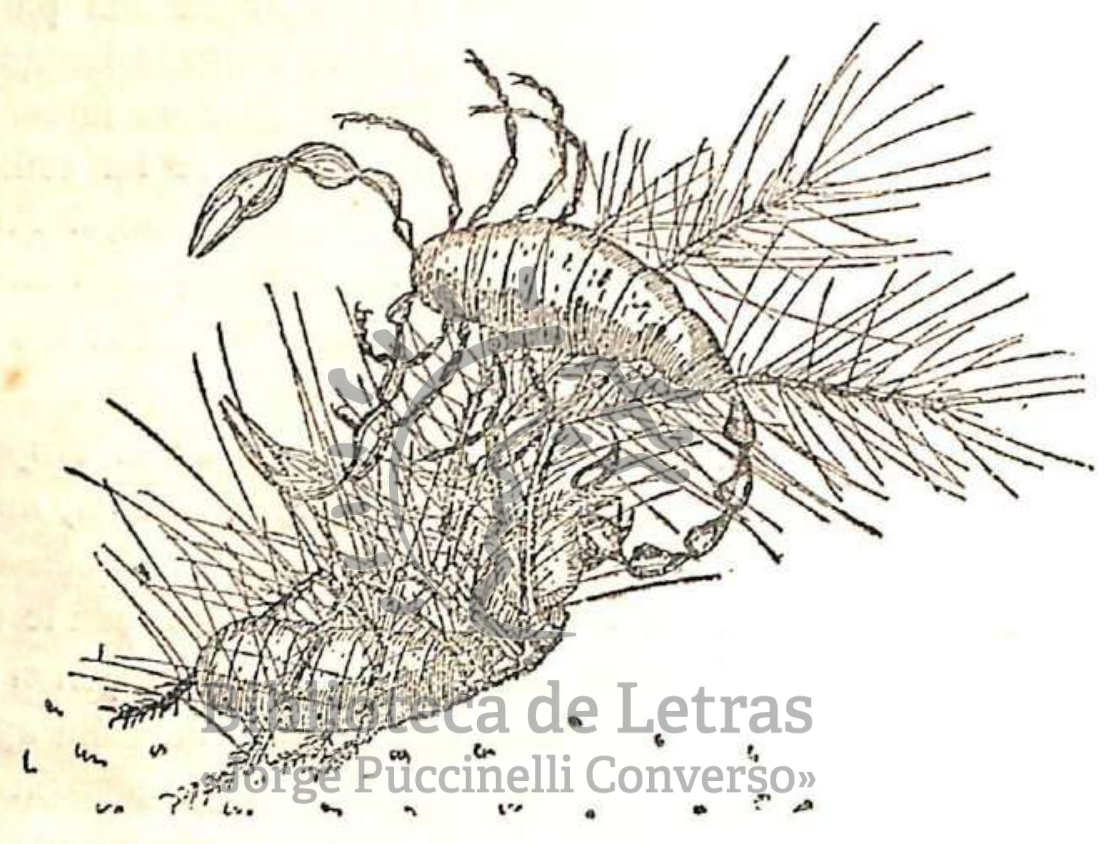

Fig. 12. El solífugo amputa al escorpión la extremidad venenosa de la cola.

Son asimismo insostenibles las teorías modernas del instinto a base de hábitos que se heredan o tropismos inevitables. Si se tratase de acciones consolidadas por la repetición hasta formar hábitos que acaban por transmitirse a los descendientes, surgen las objeciones siguientes: $\mathrm{r} .^{\circ}$ hay infinidad de actos instintivos que no pueden manifestarse sino una vez en la vida del individuo; $2 .^{\circ}$ las acciones instin- 
tivas tienen siempre una finalidad, por tanto, no pueden formarse por la mera repetición, sino por su teleología primaria - actos sin significación vital no tienen por qué repetirse hasta transformarse en hábitos; $3 .^{\circ}$ el hábito adquirido no se puede transmitir a los descendiente, pues hasta hoy todas las investigaciones prueban que sólo se transmite a los descendientes lo que se ha recibido por herencia de los padres, salvo el caso de las mutaciones, que nada tienen que ver con el hábito. La teoría según la cual el instinto depende de la asociación de acciones puramente fisicoquímicas, sin entidad psíquica, es hoy insostenible, pues los propios tropismos, que se reputaban como thanifestaciones de esta índole, se ha demostrado que en gran número de casos son verdaderos actos con sentido supramecánico. En el laboratorio de Buytendijk se ha ecclarecido que los animales aprenden a vencer en determinaclas situaciones la propensión inherente al tropismo, lo que jamás ocurriría si éste fuese determinado causalmente. Los tropismos a menudo son aspectos de la condycta que corresponden a manifestaciones de las necesidades de los aninafes, movimientos de exploración o de restautraçen Pe fan norma ecologica o productos artificiales de la experimentación. "Principalmente cuando el animal es expuesto a condiciones artificiales - afirma RuSSELL - presenta aquellas respuestas forzadas y automáticas a los estímulos físicos, que de acuerdo con la teoría de los tropismos es la base de toda conducta. En realidad, los tropismos son en muy grande medida productos de laboratorio, fruto de exposiciones a estímulos artificiales y contrarios a la naturaleza". Sería interesante saber cómo explican los teóricos del instinto-tropismo la formación de actividades como la de las hormigas melíferas. En una de las especies, por ejemplo, hay obreras especializadas en apode- 
rarse de la miel segregada durante un breve período del año por la nuez de agallas de una variedad de roble. Al retornar al nido estas obreras entregan su preciosa carga a otras hormigas, verdaderas hormigas-odire, que reciben la miel hasta que su abdomen adquiere el aspecto de un esfera, las cuales son colgadas, como recipientes inertes, unas junto a otras, en la bodega del hormiguero. Así se conservan esos reservorios vivos de miel hasta que llegue le época en que sea necesario consumir su contenido (Fig. I3).

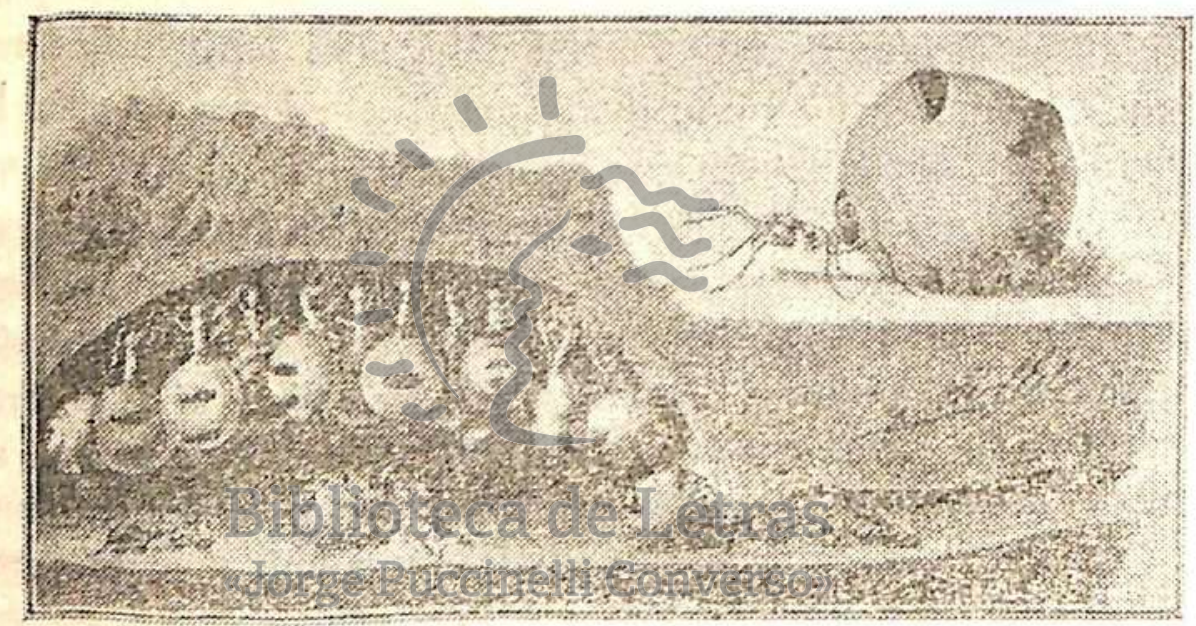

Fig. 13. Cueva de hormigas melíferas pendientes del techo.

Otra cuestión es saber si el instinto se completa con otras actividades psíquicas: la imitación, el hábito, la memoria, la experiencia adquirida individualmente, la inteligencia. Los animales solitarios, especialmente los insectos no sociales, son los que ofrecen la actividad instintiva más pura y especializada. Pero, en general, la vida activa tanto de los animales llamados inferiores cuanto de los superiores implica la intervención de otros factores psicológicos, en proporción variable según las condiciones de existencia de 
cada especie: la influencia de los padres sobre los hijos, la organización social etc. De ordinario los críticos de FABRE, incluso el imparcial y objetivo Hingston, afirman que para él no existe la inteligencia, por lo menos en lo que concierne a los insectos. Para desvirtuar semejante error transcribo un párrafo en que FABRe es muy explícito sobre el particular: "Pero con su ciencia rígida que se ignora - escribe el maestro de Serignan-, el instinto puro, si estuviese solo, dejaría al insecto desarmado en el perpetuo conflicto de circunstancias. Dos momentos no son idénticos en la duración; si el fondo permanece el mismo, cambia lo accesorio; lo imprevisto surge por doquiera. En este conflicto confuso es necesario un guía para buscar, aceptar, rechazar, escoger, preferir esto, no hacer caso de aquello, sacar, en fin, partido de lo que la ocasión puede brindar de utilizable. Ciertamente, el insecto posee este guia, en un grado incluso evidente. Es el segundo deninio de su psiquis. Ahí es consciente $y$ perfectible por ta experiencia. No osando llamar inteligencia a esta aptitud Pudimentaria, título demasiado clevaclo para ella, jollamaré discominiento: El insecto, en sus más altas prerrogatios, discieme, nace differencia de una cosa con otra, en el "erefsele stf aproximadamente" (Sonvenirs cutomologiques, tomo IV, p. $73)$.

Para terminar resumiré un bello ejemplo, debido a la observación de FABRE, que demuestra la colaboración del instinto con el "discernimiento" en la conducta de los insectos. Se trata de las vicisitudes del coleóptero meloide sitaris humeralis, cuya larva, ínfimo piojillo negro, es parásito de una abeja, el antóforo. Durante todo el invierno, a la entrada de sus galerias, sobre la pendiente de un declive soleado, espera la larva el advenimiento de la eclosión primaveral 
de las abejas. Al salir de entre éstas un macho antes que las hembras, que son las codiciaclas, el aspirante a parásito, que ambula en expectativa de la ocasión propicia, se prende con sus ganchudas uñas al joven recién nacido que sale a correr mundo, y no se separa de él hasta que se da cuenta de que no es el huésped que le conviene, pues su porvenir con este varón sería fatal, đado su género de vida. En tales condiciones espera la ocasión favorable, que será cuanclo su huésped frustráneo - tomado por equívoco - haga la corte. Es entonces cuando realiza el cambio, pasando a la hembra, en la que el diminuto gusanillo se disimula hábilmente para poder cumplir su propio destino y el de su estirpe. Llegado al fondo de la galería de la abeja dedicada a preparar su panal, "acecha entonces el momento preciso de la puesta, para instalarse sobre el huevo y dejarse deslizar al mismo tiempo sobre la superficie de la miel, a fin de sustituirse al futuro hijo del antóforo $y$, habiendo sentado plaza, aprovecharse de sus víveres y de su casa".

Al colocar el instinto dentro del marco de la bioesfera reconozco que Hayion edimanismoenmagente en la naturaleza. La finalifar dwe seimanifiestaestoel instinto revela la misma idealidad quie da forma y nexo al conjunto de la creación. Son expresiones diferentes de ese logos o razón creadora tanto las conexiones de la bioesfera y la organización y funcionamiento de cada ser vivo cuanto el instinto y la inteligencia.

No he considerado sino los instintos animales. Los del hombre constituyen proceso distinto, al que no es aplicable la clefinición propuesta. Más que instintos, el ser humano tiene necesidades e impulsos instintivos. Capaz de conciencia de sí mismo y cle pensamiento con iđeas universales, el hombre no es sólo movil movido, como el animal, sino tam- 
bién moril que se mueve. Aunque el espíritu regla el cosmos todo, sólo en nuestra conciencia revela su luz y con ello hace posible la libertad moral.

\section{Observación final}

Para Goethe "la mayor felicidad que podemos encontrar en la naturaleza es inquirir lo investigable y admirar lo inescrutable". Por la indole misma de este ensayo, una tentativa de conjugar la ecología con la psicología, no he insistido lo bastante en el segundo de los aspectos señalados por el gran poeta y naturalista. Ahora quisiera referirme simplemente a la manifestación de una finalidad puramente artística en las obras de la creación, finalidad tan obvia como la utilitaria. A este propósito es todo un símbolo la violeta, con sus dos clases de flores. Las llamadas "cleistóga-mas", ocultas debajo de las hojas, con una corola rudimentaria o sin ella, que preparan las semillas, y las otras, las que todos advertimos y admiramos, completamente inútiles, gracioso ormamento de la naturaleza.

En realidad, elibenefícrocmás Grectosoaque obtiene el hombre del examen țerkenaturahozdi noes/eanto el saber científico cuanto el sentimiento de maravilla y reverencia, el cual expresa Abed Bonnard de modo insuperable en las frases finales de su ensayo sobre el mundo de los peces: "Debemos aprencler a poner nuestra alma en posesión de las riquezas del mundo. Si todo lo que hay de aves maravillosas viniese a jugttetear en torno nuestro, nos creeríamos transportađos a un planeta más favorecido, más dichoso que el nuestro. Si todas las mariposas de la tierra entrasen una mañana en nuestra habitación, nos parecería recibir, en lugar de nuestra molesta correspondencia cotidiana, cartas mágicas de todas las hadas y, con el alma dividicla entre mil sen- 
saciones deliciosas, no querrímos conocer sino el lujo y la belleza de esta embriaguez. Pero también si no percibimos sino una sola ave que nos mira gentilmente del extremo de su rama, si no vemos arremolinarse una sobre otra sino dos de esas mariposas, de las más comunes, blancas y manchadas de gris como la flor del haba, si el océano no nos muestra en un actuario sino un poco de la moneda espléndida que esconde en sus abismos, es menester que cada una de estas sensaciones nos rememore los recursos y maravillas del planeta que nos es dado en reino y que, poseído en parte por los conquistadores, lo es totalmente por los poetas. Es muly cierto que la tierra está cargala de demasiados sufrimientos y nada es más fácil que ponenen evidencia la miseria y la crueldad que muestra la y/da. Sin embargo, es también el lugar de un encantamiento muy real; este aspecto no cuenta menos que los otros, $y$ debemos disfrutar locamente, con éxtasis de artista, deopoeta y de niño, de esta fiesta adorable a la que somos invitados por Dios".

\section{Biblioteca de Letras "Jorge PuBiBiabarafuargo"}

Camilo Acqua: "Esistono fenomeni psicologici nei vegetali?", Scientia, 1914, No. 2.-Friedrich Alverdes: Leben als Sinnverwirklichung, Stuttgart, 1936.-Aristótreles: De l'âme (De anima), Paris, 1934 (Trad. de J. Tricot).-Arthur Berger und Josef Schmid (con muchos colaboradores): Das Reich der Tieve. Das Tier in seinem Lebensraum, 3 ts., Berlin, 1936-1937.-Henri Bergson: L'évolution créatrice, Paris, 1921.-August Brer: Die Seele, München, 1939.-E. Bleuler: Die Psychoide als Prinzip der organischen Entwicklung, Berlin, 1925.-ABes Bonnard: Le monde des

" Después de escrito este trabajo, mi eultísimo anigo Dr. Gino Bianchini me ha ofrecido la oportunidad de conocer la obra Maravillas de la vida animal Barcelona, s. anglés) publicada bajo la direceión de J. A. Hammerton, 4 ts., 
poissons, Paris, 1937.-E. L. Bouvier: La vie psychique des insectes, Paris, 1922.-F. J. J. BuxtendIK:Wege zum Verstaendnis der Tirre, Leipzig, 1938.-Mario F. Canella: Orientamenti della moderna biologia, Bologna, 1939.-G. CoLosi: "Le basi della eongruenza fra il mondo organizzato e l'ambiente", Siontia, 1940, Nos. 2 y 3 .Lucten Cuénot: La genèse des espèces animales, Paris, 1932.Honorio Delgado, Mariano Iberico: Psicología Lima, 1933.- HoNorio Delgado: "Psicologia general y psicopatología de las tendencias instintivas", Revisla de Neuro-Psiquitria, 1938 No. 3.-Hans Druesch: Philosophie des Organischen, Leipzig, 1921.-Bernmard Dufrken: Entwicllungsbiologia und Ganzheit. Ein Boitrag zur Neagestallung des Wcltbildes, Leipzig, 1936.-Eugene Everard: Le monde des abeilles, Paris, 1928.-J. H. F.IBRE: Souvenirs entomologiques. Eludes sur l'instinct et les moeurs des insectes, Edition definitive illustrée, 10 ts., Paris, 1924-1934.-Werner Fischel: Psythe und Leislung der Tiere, Berlin, 1938.-Raoul Francé: Bios. Die Gezclze der Well, 2 ts., Müuchen, 1921.-R. Francé: Les sens de la plante ('T'rad. del alemán), Paris, 1937.-KARL Friederichs: Oeloologie als Wissenschaft von etor Natw oder biologische Raumforschung, Leipzig, 1937.- F. W. G.⿲丿⿺乚㇒匕is? The animal world, London., s. a.-CH.s W. Greese: "The physiology of the spawning migration', Physiological Revioys, 1926, No. 2.-P. HAcHeT-Souplet: Les sociélís d'animaur, Paris, 1928.-R. 'W. G. Hingston: Problémes de l'instinct el de l'intelligened chez les insectes (Trad. del inglés), Paris, 1931- H. Eliot Howndo: An introduction to the study of bird bchaviour. Cambridge, 1929.-KarL Jarmer: Das Seelenleben der FischeBilûndhene1928. A-Cumide ISAGEs: Der Geist

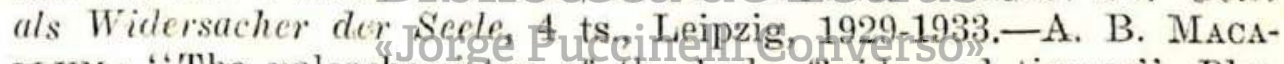
LLUM: "The paleoehemistry of the body fluids and tissues", Physiological Revieus, 1926, No. 2.-Constantin Mayer: "Untersuchungen mit Pflanzengallen', Deutsiche Medizinische Wochenschrift, 1938, No. 48.--René M.Aezedier: Le roman du saumon, Paris, 1935. -Melchior Palńgyi: Wahrnehmungshehre, Leipzig, 1925.-Umberto Pierantoni: "I mierorganismi nell'economia animale", Sientia, 1925, No. 4.-Prerre-Jesn : La psychologie organique, Paris, 1937.-E. S. Russelu: The behaviour of animals, London, 1938.H. Sprmann: "Neue Einsichten in das Wesen der tierisehen Entwicklung', Deutsche Medizinische Wochenschrift, 1938, No. 27.P. Temlinard de Chardin: "L'histoire naturelle du monde. Réflexions sur la valeur et l'avenir de la Systematique", Scientia, 1925, No. 1.-Maurice Thomas: "La notion de l'Instinct, connaissance innée, et sa tenue devant la méthode expérimentale', Scientia, 1936, No. 5.-J. ArThur THomson: The system of animate nature, 2 ts., 
London, 1920.-J. voN UExkUELL: Theoretische Biologie, Berlin, 1920.-Jakoв von Uexkuell: Der unsterbliche Grist in ler Natur. Gespraeche. Hamburg. 1938.-PaUl Valéry : Les coquillages, Paris, 1936.-PAUL VIGNON: Intraduction à la biologie exprimentale. Les êtres organisés: Activités, instincts, structures, Paris, 1930.A. Hyatt Verrill: Moeurs étranges des insectes (Trad. del inglés), Paris, 1938-Aloys WenzL: Metaphysile der Biologie von Heute, Leipzig, 1938.-Richard Wortereck: Grundzuege einer allgemoine Biologie, Stuttgart, 1932.

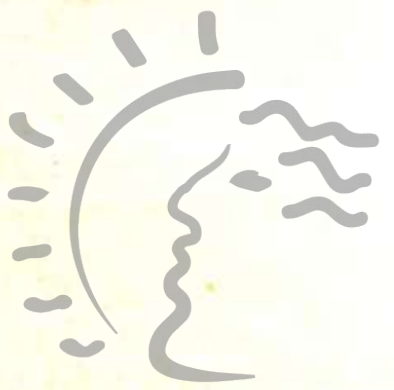

Biblioteca de Letras "Jorge Puccinelli Converso" 